DR PAUL CLARKSON (Orcid ID : 0000-0002-0778-312X)

DR JANE HUGHES (Orcid ID : 0000-0001-5568-9659)

PROFESSOR BRENDA ROE (Orcid ID : 0000-0001-8227-0116)

Article type : Review

\title{
Systematic review: Effective Home Support in Dementia Care, components and impacts - Stage 2, effectiveness of home support interventions
}

\section{Running head: Systematic review of effectiveness of dementia home support interventions}

Paul CLARKSON PhD, MSc, BA, Research Fellow

Personal Social Services Research Unit

Division of Population Health, Health Services Research and Primary Care

School of Health Sciences

Faculty of Biology, Medicine and Health

University of Manchester

Manchester Academic Health Science Centre

Manchester, UK

Jane HUGHES PhD, MSc, BA (econ), Senior Research Fellow

Personal Social Services Research Unit

Division of Population Health, Health Services Research and Primary Care

School of Health Sciences

Faculty of Biology, Medicine and Health

University of Manchester

Manchester Academic Health Science Centre

Manchester, UK

Brenda ROE RN, RHV, PhD, Professor of Health Research

Edge Hill University

Evidence-based Practice Research Centre

Faculty of Health \& Social Care

Ormskirk, L39 4QP

Clarissa M. GIEBEL BSc, MSc, Research Assistant

Personal Social Services Research Unit

Division of Population Health, Health Services Research and Primary Care

This article has been accepted for publication and undergone full peer review but has not been through the copyediting, typesetting, pagination and proofreading process, which may lead to differences between this version and the Version of Record. Please cite this article as doi: $10.1111 /$ jan. 13460

This article is protected by copyright. All rights reserved. 
School of Health Sciences

Faculty of Biology, Medicine and Health

University of Manchester

Manchester Academic Health Science Centre

Manchester, UK

David JOLLEY MSc, MBBS Medicine, Honorary Reader

Personal Social Services Research Unit

Division of Population Health, Health Services Research and Primary Care

School of Health Sciences

Faculty of Biology, Medicine and Health

University of Manchester

Manchester Academic Health Science Centre

Manchester, UK

Fiona POLAND PGCHE, PhD, Professor of Social Research Methodology School of Health Sciences

University of East Anglia,

Norwich, UK

Michele ABENDSTERN PhD, BA, PG Dip, Research Associate

Personal Social Services Research Unit

Division of Population Health, Health Services Research and Primary Care

School of Health Sciences

Faculty of Biology, Medicine and Health

University of Manchester

Manchester Academic Health Science Centre

Manchester, UK

Helen CHESTER PhD, MSc, BA, Research Associate

Personal Social Services Research Unit

Division of Population Health, Health Services Research and Primary Care

School of Health Sciences

Faculty of Biology, Medicine and Health

University of Manchester

Manchester Academic Health Science Centre

Manchester, UK

David CHALLIS PhD, MSc, BA, Professor of Community Care Research

Personal Social Services Research Unit

Division of Population Health, Health Services Research and Primary Care

School of Health Sciences

Faculty of Biology, Medicine and Health

University of Manchester

Manchester Academic Health Science Centre

Manchester, UK

\& members of the HoSt-D (Home Support in Dementia) Programme Management Group. 
Corresponding author: Dr Paul Clarkson, address above, Tel: +44 (0)161-275 5674;

Fax: +44 (0)161 275 5790; E-mail: paul.clarkson@manchester.ac.uk.

\title{
Acknowledgements
}

This research was funded by the National Institute for Health Research (NIHR) under its Programme Grants for Applied Research (Grant Reference Number: DTC-RP-PG0311-12003). The views expressed are those of the authors and not necessarily those of the NHS, the NIHR or the Department of Health. We would like to thank Rebecca Hays for initial help in developing the search strategies and our PPCl group for their comments from the synthesis. Other members of the Programme Management Group are: Professor Martin Orrell, Narinder Kapur (University College London); Professor Linda Davies, Professor Chris Roberts (University of Manchester); Jean Tottie (TIDE-Together in Dementia Everyday); Professor lan Russell (Swansea University) and Reagan Blyth (Pennine Care NHS Foundation Trust).

\section{Conflict of interest statement}

No conflict of interest was declared by the authors in relation to the study itself. Note that Brenda Roe is a JAN editor but, in line with usual practice, this paper was subjected to double blind peer review and was edited by another editor.

\section{Funding statement}

This research was funded by the National Institute for Health Research (NIHR) under its Programme Grants for Applied Research (Grant Reference Number: DTC-RP-PG0311-12003).

\begin{abstract}
Aim. To explicate the outcomes of home support interventions for older people with dementia and/or their carers to inform clinical practice, policy and research.
\end{abstract}

Background. Most people with dementia receive support at home. However, components and effectiveness of home support interventions have been little explored.

Design. Systematic review with narrative summary.

This article is protected by copyright. All rights reserved. 
Data sources. Electronic searches of published studies in English using PubMed, Cochrane Central Register of Controlled Trials, PsychINFO, CINAHL, Applied Social Science Index and CSA Social Services Abstracts. Databases and sources were searched from inception to April 2014 with no date restrictions to locate studies.

Review methods: The PRISMA statement was followed and established systematic review methods used. Using 14 components of care for people with dementia and their carers, identified previously, data across studies were synthesized. Interventions were grouped and described and effectiveness ratings applied. Qualitative studies were synthesized using key themes.

Results. Seventy studies (four qualitative) were included. Most were directed to carers and of high quality. Seven interventions for carers and two for people with dementia were identified, covering $81 \%$ of studies. Those relating to daily living, cognitive training and physical activity for people with dementia were absent. Measures of effectiveness were influenced mainly by the intensity (duration and frequency) of interventions. Those containing education, social support and behaviour management appeared most effective.

Conclusion. These interventions reflect emergent patterns of home support. Research is required to identify effective interventions linked to the stage of dementia, which can be applied as part of routine clinical care.

Keywords: dementia, nursing, home support, carers, caregivers, systematic review, interventions 


\section{Summary statement}

\section{Why is this research or review needed?}

- There is no cure for dementia currently and as people live longer the costs associated with its management will increase.

- Most studies report non-pharmacological interventions undertaken in nursing/care homes and not at home where most people with dementia live with their carers.

- Studies of non-pharmacological interventions for people with dementia and their carers often lack detailed descriptions of their components and effectiveness.

\section{What are the key findings?}

- Nine types of home support interventions were identified.

- Most interventions of home support for people with dementia were targeted on their carers and comprised more than one component.

- The effectiveness of particular interventions varied.

\section{How should the findings be used to influence policy/practice/research/education?}

- This review informs clinical practice and service commissioning about effective support for people with dementia living at home with their carers.

- Further research is required to gather evidence about home support for people with dementia which can be replicated by practitioners in routine care.

This article is protected by copyright. All rights reserved. 


\section{INTRODUCTION}

Dementia is a major international public health concern with a growing number of people affected by the condition, either directly or indirectly through caring for someone with dementia, with associated high costs of treatment and care (Rosser \& Knapp 2015). In 2015, worldwide, 9.9 million new cases of dementia were estimated each year, one case every 3.2 seconds, leading to a figure of 46.8 million people living with dementia. This figure is projected to reach 74.7 million in 2050 (Alzheimer's Disease International, 2015). It is estimated that over one million people were living with dementia in the United Kingdom (UK) by 2015, with currently over seven percent aged 65 or above having dementia (Prince $e t$ al. 2014). As the condition progresses, a reduction in independence leads to people with dementia being increasingly reliant on support, which, in conjunction with increased behavioural and cognitive difficulties, increases carer burden (Grau et al. 2015; Sutcliffe et al. 2016). Consequently, non-pharmacological interventions for people with dementia living at home are a critical element in improving dementia care.

\section{Background}

An estimated 60 percent of people with dementia live in private households in the UK (Prince et al. 2014). Therefore, home support for these people and their carers is an important aspect of care. It includes the contribution of informal carers (spouses or children), estimated to provide about 40 percent of care (Schneider et al. 2003), a substantial amount of it unpaid (Department of Health 2009). Additionally, formal home support from professionals and support workers is available (Wilberforce et al. 2013). Many dementia home support interventions have been reported. For example care coordination by an interdisciplinary team including the provision of information about dementia, skill-building and regular monitoring by (Samus et al. 2014) and telephone-based support for family caregivers (Winter \& Gitlin 
2006). However, further investigation is required relating to the efficacy of such interventions in terms of effectiveness and outcomes. In particular, it is unknown which components of these interventions might offer the greatest benefits to people with dementia and their carers.

This paper is part of a two-stage synthesis to marshal evidence of home support arrangements for people with dementia and their carers, concerning their effectiveness (Clarkson et al. 2016). It presents a systematic review evaluating evidence for the effectiveness of home support interventions provided to people with dementia and their carers. This builds on an earlier review (stage 1), which evaluated evidence for the effectiveness of psychosocial support irrespective of setting, which identified several components both for people with dementia and their carers (Clarkson et al. 2017). The review is part of a wider research programme (National Institute for Health Research, Programme Grants for Applied Research No. DTC-RP-PG-0311-12003). Overall this review will provide evidence to guide clinical practice in home support and assist in the commissioning and redesign of multidisciplinary approaches to the care of older people with dementia and their carers.

\section{THE REVIEW}

\section{Aim}

The aim of this systematic review was to explicate the outcomes of home support interventions for older people with dementia and/or their carers that rely on one or more of the components identified previously (Clarkson et al. 2017). This includes whether there are differences in effectiveness between different stages of dementia.

This article is protected by copyright. All rights reserved. 


\section{Design}

A systematic review of primary studies with high external validity (that is, where the intervention had or could have been implemented in the routine practice of home support in the UK) was undertaken. Both qualitative and quantitative studies were included. The review followed the PRISMA statement and established guidelines for conducting and reporting systematic reviews (Centre for Reviews and Dissemination 2009; Moher et al. 2009; Liberati et al. 2009) PRISMA add references). Detailed information on the methodology of this review is in the published protocol, including the inclusion criteria for studies (Clarkson et al. 2016). In this, home support interventions were defined as those providing formal support and were categorized, as providing information, support, education or therapy. The review was registered with PROSPERO (Reference/ID No CRD42014008890).

\section{Search methods}

Search strategies for identifying relevant studies were broad but subject to database-specific terms to enable appropriate studies to be identified. These terms were derived after discussion between the investigators, piloted and tested by an experienced systematic reviewer prior to the development of the protocol and included: dementia, Alzheimer Disease, home care services, social support (see Supplementary Information Table S1 for further information). Two reviewers searched electronic databases, PubMed, Cochrane Central Register of Controlled Trials, PsychINFO, CINAHL, Applied Social Science Index and CSA Social Services Abstracts (Clarkson et al. 2016). Reference lists of relevant citations were checked and hand searches of relevant journals known to the investigators were also undertaken to elicit additional references, including a previous literature review by the investigators (Challis et al. 2010). No date restrictions were applied and all databases and sources were searched from inception up to April 2014 to locate studies published in English.

This article is protected by copyright. All rights reserved. 


\section{Search outcome}

Two reviewers selected studies for inclusion and agreed exclusions. One researcher screened the titles and abstracts of all potentially relevant citations against the inclusion criteria, with a second reviewing these decisions. Where decisions were not clear, the full-text of the study was read and uncertainties resolved through discussion with a third, independent reviewer. The two reviewers then extracted data concerning the key characteristics of those studies meeting the inclusion criteria.

\section{Quality appraisal}

Using checklists of criteria two reviewers assessed the quality of the included studies independently. For quantitative studies, the Quality Assessment Tool for Quantitative Studies was used (EPHPP 2003; Deeks et al. 2003). It assesses selection bias, study design, confounders, blinding, data collection methods and withdrawals and dropouts. Scores range from 1 (strong, with no weak ratings) to 3 (weak, with two or more weak ratings). For qualitative studies, the Critical Appraisal Skills Programme (CASP) checklist (Public Health Research Unit 2006) was employed with ratings provided by two reviewers. It comprises 10 questions designed to assist reviewers to appraise qualitative research by thinking systematically about the key issues of rigour, credibility and relevance. Discrepancies for both types of data were resolved through discussion.

\section{Data abstraction}

A standardised electronic form, based on guidance was used to extract data about the interventions in the identified studies. This was based on the PICOS (Population, Interventions, Comparators, Outcomes and Study designs) Framework (Centre for Reviews and Dissemination 2009). The form comprised data on: study reference and setting; study 
characteristics (aims/objectives, inclusion criteria, participant recruitment); study design; focus of intervention (e.g. carers, people with dementia); participant characteristics (number, age, gender, stage of dementia); the intervention description (how delivered, intensity duration and frequency, by whom); relevant outcomes; and main findings. It was piloted and refined on a sample of five studies before full data extraction.

\section{Synthesis}

Studies had a variety of objectives and research designs. A narrative summary was therefore undertaken to determine the extent to which home support interventions relied on the components identified previously (Clarkson et al. 2017) and to rate evidence concerning their effectiveness. Fourteen theory-linked components (nine for people with dementia and five for carers) were used. These were: for the person with dementia - sensory enhancement/relaxation, social engagement, cognitive training, emotional support, physical activity, environmental modification, behaviour management, daily living assistance and care coordination; for the carer - education/advice, social support, behaviour management, emotional support and respite. A coding manual was developed to enable reviewers to judge, independently, the presence or absence of each component in the published studies. A matrix (Teri et al., 2005a) described the extent of the overlap of components in different studies.

Data were synthesized by grouping studies according to interventions, developed and agreed by the reviewers. In this review, interventions were defined as distinct, coherent and intentional acts of involvement aimed at alleviating difficulties. Thus, multiple studies reporting on the same intervention were grouped together to inform judgments of effectiveness (Carr et al. 2011). These were presented by their predominant component or component-mix. Effectiveness ratings were based on: statistically significant change (scored 
as: non-significant $=0$, significant $=1$ ); effect size ('small' $=0$, ' medium' $=1$, 'large' $=2$ ); and intensity (the amount of exposure - duration and frequency - participants received from the intervention; scored as 'low intensity'=1, 'high intensity'=2.). Scores for each of these domains were summed to give an overall effectiveness score; see supplementary information, Table S2 for details of the calculation. The resulting synthesis comprised descriptions of the interventions in terms of context, their mechanisms (their theory of change), the role and type of staff involved in delivery and outcomes.

As detailed in the protocol, to synthesise data from qualitative studies, key themes were identified with which to determine how and to whom outcomes were generated. This followed Thomas \& Harden's (2008) three stage approach: coding of text 'line-by-line'; the development of 'descriptive themes'; and the generation of 'analytical themes'. The analytical themes were generated from the 14 components above to provide an interpretive framework similar to that used in the quantitative summary. For example, studies were systematically appraised to establish the acceptability of interventions to people with dementia and their carers.

\section{RESULTS}

\section{Study selection}

A total of 603 citations were initially extracted, of which 160 were reviewed by title and abstract. Figure 1 shows the PRISMA (Moher et al. 2009) flow diagram for included studies. Seventy papers met the inclusion criteria. Three studies, where costs were the only outcome, were excluded.

This article is protected by copyright. All rights reserved. 


\section{Study characteristics}

Tables 1-3 describe the included studies reporting home support interventions. Most $(\mathrm{N}=37$; $53 \%)$ were conducted in the United States (US), followed by the UK $(\mathrm{N}=13 ; 18 \%)$ and the remainder in other countries including Taiwan, Finland and China. Almost all were directed towards family carers: either as a primary focus $(\mathrm{N}=33 ; 47 \%)$ or with people with dementia ( $\mathrm{N}=35 ; 50 \%)$. Two studies focused solely on people with dementia.

Twenty studies (29\%) failed to specify the severity or stage of dementia. Of the remaining $(\mathrm{N}=50,71 \%)$, most were directed towards carers or people with dementia in both early and later stages. A minority of studies addressed the needs of people exclusively in the early $(\mathrm{N}=7 ; 10 \%)$, or in the later $(\mathrm{N}=10 ; 14 \%)$, stages.

In terms of research design most studies $(\mathrm{N}=57 ; 81 \%)$ were RCTs. Nine (13\%) were quasiexperimental interventions and four $(6 \%)$ were qualitative. Interventions lasted between one and 216 months (18 years). The largest one (Newcomer et al. (1999) included 2,731 (2,576) participants in the intervention (control) group, whilst the smallest (Sutcliffe \& Larner 1988) consisted of six participants in the intervention and five in the control group (see Tables 1,2 and 3).

The quality rating for the quantitative studies $(\mathrm{N}=66)$ is also specified in the tables (Tables 13). The majority $(\mathrm{N}=37 ; 56 \%)$ were of high quality, with six (9\%) categorized as weak. For the qualitative studies, two had low quality, one medium quality and one was rated of high quality. Overall, the 70 studies reported on 63 different interventions, with some studies reporting on different outcomes from the same intervention (e.g. Mittelman et al. 2004a; 2004b).

This article is protected by copyright. All rights reserved. 


\section{Synthesis}

The quantitative and qualitative studies are reported separately. In the first, the groupings of 14 components ( 5 for carers and 9 for people with dementia) identified previously (Clarkson et al. 2017) and detailed above, were employed. These are described as interventions and subsequently measures of effectiveness are applied to them (Table 4). Finally, findings from the qualitative data are reported, reflecting some of the 14 components referred to above.

\section{Groupings of components}

There were 14 single-component and 52 multi-component carer studies and 21 singlecomponent and 15 multi-component studies for people with dementia identified (see supplementary information Tables S3 and S4). The components identified in these studies were grouped together into interventions to capture the most prevalent approaches for both carers and people with dementia. This grouping included over four fifths $(81 \%)$ of the studies in the review.

The interventions are described in Table 4. Seven interventions were identified for carers, based on five components. Education/advice and behaviour management were the most frequent components for carers and were often jointly employed. Information and advice was frequently provided alongside behavioural techniques, whereby carers were educated about the possible causes of their relative's behaviour problems. The interventions identified were a single-component approach, involving only behaviour management ( $\mathrm{N}=8$ studies); and a multicomponent intervention employing education/advice, emotional and social support $(\mathrm{N}=6$ studies). The remainder employed: education/advice and behaviour management $(\mathrm{N}=11$ studies); plus emotional support ( $\mathrm{N}=5$ studies); plus social support ( $\mathrm{N}=5$ studies); plus emotional and social support ( $\mathrm{N}=6$ studies). Finally, one approach involved all five 
components: education/advice, behaviour management, emotional support, social support and respite ( $\mathrm{N}=3$ studies).

Two single component interventions were identified for people with dementia, from 9 possible components: one focusing on care coordination $(\mathrm{N}=7$ studies) and the other on environmental modifications ( $\mathrm{N}=6$ studies). In describing the most prevalent groupings of components, seven components previously identified were not included (sensory enhancement/relaxation; social engagement; cognitive training; emotional support; physical activity; behaviour management; and daily living assistance) (Clarkson et al. 2017). The least represented components in this review of home support interventions were: sensory enhancement/relaxation, which was present in only one study (Torkomani et al. 2014); cognitive training in only three (Quayhagen et al. 2000; Davis et al. 2001; Graff et al. 2007) and physical activity in only four (Teri et al. 2003; Gitlin et al. 2008; Eloniemi-Sulkava et al. 2009; Steinberg et al. 2009). The inclusion of these studies would have reduced the number of interventions it was possible to categorise and therefore the evidence available (see supplementary information Table S4). As noted in Table 4, a range of staff were employed in undertaking the interventions, including professionally and non-professionally qualified personnel and researchers.

\section{Effectiveness}

The nine interventions, described above, comprising the most prevalent groupings of components, were selected to synthesise evidence relating to effectiveness. These are described in Table 4 with exemplars. Two criteria, effect size and intensity had most influence on the rating of effectiveness. Most studies reported statistically significant change in at least 
one outcome. The statistics used for calculating the effectiveness rating for each study are in supplementary information, Table S4. The most salient findings are summarized below.

All interventions included studies with a range of effectiveness ratings. A larger number of components within an intervention did not necessarily increase effectiveness. Hence, the approach for carers containing all five components (C7, Table 4) was no more effective, in terms of the range of effectiveness ratings, than other approaches. However, there was a tendency for the approach containing education/advice, behaviour management and social support (C5, Table 4) to have a higher range of effectiveness than others.

Components were linked to a range of outcomes, including everyday functioning, behaviour, cognition and delaying nursing/care home admission. A number were multicomponent interventions. The mix of two components, education/advice and behaviour management $(\mathrm{C} 3$, Table 4), was the most frequent intervention approach, which effectively reduced carer burden, problem behaviour and improved well-being. This might reflect the fact that teaching carers to manage problem behaviours most often involves information and advice about the causes of such behaviours and about the condition as such. Another set of interventions comprised a different mix of components, providing education/advice, emotional and social support to carers (C2, Table 4). Often this consisted of face-to-face, telephone, or internetbased support groups and individual counselling, where carers were listened to and could exchange their experiences of caring for someone with dementia. The approach was used to reduce the rate of nursing/care home admissions and the promotion of carer well-being.

Measures of effectiveness were also captured in the two single component interventions for people with dementia (P1 and P2, Table 4). Six studies employing environmental 
modifications were rated low to moderately effective, although all reported significant improvements. These were based on the theory that removing stressors in the environment can reduce problem behaviour and increase everyday functioning of the person with dementia, such as transfers out of bed and enhance carer well-being. A range of effectiveness ratings were identified for care coordination. The primary goal of most was to delay or reduce nursing/care home admission (Lawton et al. 1989; Chien \& Lee 2008, 2011; Challis et al. 2009). Most studies were RCTs and specifically designed to test the efficacy of a specific intervention. However, Tibaldi et al. (2004) compared the effectiveness of two different approaches to care. The care coordinated home hospitalisation service was effective in alleviating carer burden and reducing problem behaviours, compared with those admitted to a general medical ward.

\section{Qualitative findings}

For qualitative studies, key themes were identified to determine how outcomes were generated. Three focused on carer skill building (Farran et al. 2003, 2004; Kelly et al. 2002). They all included the components of: education and advice, behaviour management, emotional support and the presence of social support. The remaining study focused on people with dementia and their carers (Rothera et al. 2008). Three components were also present in this: behaviour management, daily living and, for carers, emotional support.

Quality of life of the carer-person with dementia relationship was the main outcome focus of all qualitative studies, with carer burden being a specific element within it. Two linked studies (Farran et al. 2003, 2004) highlighted the need to support carers to come to an understanding of dementia as a condition and that how they manage their own feelings and behaviours can have an impact on both on the behaviour of the person with dementia and on their own well- 
being. One carer commented that they had "finally realised that it's me who has to change" (Farran et al. 2003, p. 371).

\section{DISCUSSION}

In this section, the principal findings from this systematic review are appraised in terms of the principal findings, their logical coherence and implications for clinical practice. The aim of this review was to explicate the outcomes of home support interventions for older people with dementia and/or their carers, which relied on one or more of the components previously identified (Clarkson et al. 2017). However, the descriptions of the interventions were of variable quality. Nevertheless, in terms of influence, most studies reported positive outcomes, although these were derived from a disparate group of interventions, employing differing outcome measures and sometimes were based on small samples.

Reflecting the aim of the review, the principal finding was the identification of a range of potential approaches for delivering home support to people with dementia and their carers (Clarkson et al. 2016). This has been achieved by first identifying the components of the intervention irrespective of setting and second by investigating their presence in studies administered to people with dementia and their carers at home, with an assessment of their effectiveness. All 14 components identified previously (Clarkson et al. 2017) were present in the studies included in this review. The resulting interventions covered over four fifths of these. Many interventions targeted improving behavioural problems, with studies typically teaching carers techniques to address these. Behaviour management techniques focused on the person with dementia were rare. Only two of the nine components for people with dementia were included.

This article is protected by copyright. All rights reserved. 
An interesting finding from this review was that most interventions addressed the needs of carers and not people with dementia. Their contribution to the care of people with more advanced dementia has been noted elsewhere (e.g. Starkstein et al. 2006). The management of problem behaviour by changing the response of carers was an important component of interventions in this literature review (see for example, Livingston et al. 2005). Interestingly, an intervention using this component together with education and social support revealed more evidence of effectiveness than other approaches (Chien \& Lee 1998; Burgio et al. 2003; Belle et al. 2006; Finkel et al. 2007). However, effectiveness was unrelated to the number of components within an intervention.

To what extent does the logical coherence of the nine interventions identified constitute a taxonomy? This has been described as "a formal system for classifying multifaceted, complex phenomenon according to a set of common conceptual domains and dimensions" (Bradley et al. 2007, p. 1760). The approach has been used previously to describe approaches to information sharing and assessment in a demonstration program (Chester et al. 2015). Its value is in promoting "increased clarity in defining and hence comparing diverse, complex interventions" (Bradley et al. 2007, p. 1760) by using "a common language . . . that distils [them] into their essential components" (Bradley et al. 2007, p. 1766). The interventions described and appraised in Table 4 represent a synthesis of the 14 components, identified previously, in a variety of combinations (Clarkson et al. 2017). Critically, in this review they were delivered at home. Interventions within the taxonomy included studies with a range of effectiveness ratings based on multiple outcome measures. They differed in terms of their mechanisms for promoting change and the staff groups administering the interventions, together with measures of outcomes and effectiveness.

This article is protected by copyright. All rights reserved. 
Furthermore, a taxonomy can be expanded and thus incorporate future interventions and evidence for them over time (Bazzoli et al. 1999). Thus, it provides a practical representation of the aim of this review by codifying home support interventions for older people with dementia and their carers together with evidence of effectiveness. For practitioners this could become a valuable resource. It could be expected, for example, that over time more evidence will be gathered relating to the components of interventions not captured in the taxonomy described above. These include three components of home support for people with dementia: daily living assistance, cognitive training and physical activity. However, to preserve its integrity as a taxonomy of home support, only interventions conducted in this setting should be included. This contrasts with previous research into home support for people with dementia which, whilst not a systematic review, categorised four approaches, case management, integrated care, consumer directed care and restorative care (Low \& Fletcher 2015).

What are the implications of this review and the resultant taxonomy for clinical practice? The taxonomy provides a framework to guide practitioners. However, it is not a prescriptive tool and not all the interventions reported could be replicated and transferred into routine care administered by practitioners. Moreover, an intervention is unlikely to be effective if staff do not have the appropriate skills and training to deliver it. Of the nine interventions in the review, two thirds reported nurses or nurse therapists overseeing their administration. Furthermore, a judgement has to be made as to which interventions have the potential to be effective. This review suggested that approaches containing education, social support and behaviour management have the greatest potential. Finally, within this taxonomy no distinction is made about the stage of dementia in relation to judgements of effectiveness. Therefore, successful administration of an intervention requires an assessment of potential 
utility to be made by the practitioner in the context of the progress of the condition for an individual.

\section{LIMITATIONS}

This review was subject to certain limitations. One of the inclusion criteria for the review the presence of a comparator of standard or usual care - may have excluded several qualitative studies. Typically, these tend to be small scale and of a case study design and less likely to have comparator data. Of the excluded qualitative papers $(\mathrm{N}=14)$, most $(\mathrm{N}=9)$ were excluded for this reason, illustrating the compromises inherent in the design of a systematic review with both qualitative and quantitative data. A further compromise inherent in the handling of qualitative data was that it did not explicitly follow established ENTREQ best practice guidance for qualitative research (Tong et al. 2012). Nevertheless, the majority of items documented in this (16 out of 21$)$ were adhered to in the wider review process.

There were also limitations consequent on the use of review specific measures: the component rating manual and the effectiveness rating. More generally in term of effectiveness, the number of included studies $(\mathrm{N}=70)$ made it difficult to appraise the effectiveness of each intervention, particularly when there were multiple components. Furthermore, whilst the ratings of effectiveness captured statistically significant change in at least one outcome, one of their elements - effect size - could not be calculated for some due to data limitations. Finally, it was not possible to capture all the studies within the taxonomy. Notable omissions were daily living assistance, cognitive training and physical activity for people with dementia.

This article is protected by copyright. All rights reserved. 


\section{CONCLUSION}

This review has synthesised the evidence for home support approaches directed at tertiary prevention, to ameliorate difficulties and enhance well-being. The framework applied here, presented as a taxonomy of nine interventions combining these components in different ways, has enabled interventions to be compared and gaps in knowledge and understanding to be identified. It adds to existing knowledge and facilitates knowledge transfer from research into practice for both practitioners and service commissioners. In particular, the taxonomy highlights gaps in the understanding of the value of daily living assistance, cognitive training and physical activity for people with dementia. Two further general gaps in knowledge have been highlighted in this review. The first and arguably the more important, is the paucity of research relating to the care of people with dementia at home. Allied to this, many studies omitted information on the stage of the progression of dementia, a critical determinant of potential effectiveness. Future research should address these deficits by focussing on the care of people with dementia living at home and target interventions to distinguish between early and later stage dementia.

This review has also identified that research could usefully focus on care at home and support provided to carers. A further area of enquiry emerging from this review is a requirement for the systematic analysis of user and carer preference to gauge the most valuable components of support. There is also a need to investigate the effectiveness of interventions identified through our taxonomy using robust measures of effectiveness. In this there will be value in a clear distinction regarding early and later stage dementia. The care of people with dementia at home represents a global challenge and this review highlights both evidence to guide current packages of care and gaps in the evidence base from which tailored interventions could be designed and evaluated.

This article is protected by copyright. All rights reserved. 
Author Contributions:

All authors have agreed on the final version and meet at least one of the following criteria (recommended by the ICMJE*):

1) substantial contributions to conception and design, acquisition of data, or analysis and interpretation of data;

2) drafting the article or revising it critically for important intellectual content.

* http://www.icmje.org/recommendations/

\section{References}

Afram B., Stephan A., Verbeek H., Bleijlevens M.H., Suhonen R., Sutcliffe C., Raamat K., Cabrera E., Soto M.E., Hallberg I.R., Meyer G., Hamers J.P. \& RightTimePlaceCare Consortium (2014) Reasons for institutionalization of people with dementia: informal caregiver reports from 8 European countries. Journal of the American Medical Directors Association 15(2), 108-116.

Alzheimer's Disease International. (2015) World Alzheimer's Report: The Global Impact of Dementia. Alzheimer's Disease International, London.

Askham J. \& Thompson C. (1990) Dementia and Home Care: A Research Report on a Home Support Scheme for Dementia Sufferers. Age Concern Books, Mitcham.

Bazzoli G., Shortell J., Dubbs N., Chan C. \& Kralovec P. (1999) A taxonomy of health networks and systems: Bringing order out of chaos. Health Services Research 33(6), 1683-1717.

Belle S.H., Burgio L., Burns R., Coon D., Czaja S.J., Gallagher-Thompson D., Gitlin L.N., Klinger J., Koepke K.M., Lee C.C., Martindale-Adams J., Nichols L., Schulz R., Stahl S., Stevens A., Winter L. \& Zhang S. (2006) Enhancing the quality of life of dementia 
caregivers from different ethnic or racial groups: A randomized, controlled trial. Annals of Internal Medicine 145(10), 727-738.

Bourgeois M.S., Burgio L.D., Schulz R., Beach S. \& Palmer B. (1997) Modifying repetitive verbalizations of community-dwelling patients with AD. Gerontologist 37, 30-39.

Bourgeois M.S., Schulz R., Burgio L. \& Beach, S. (2002) Skills training for spouses of patients with Alzheimer's disease: outcomes of an intervention study. Journal of Clinical Geropsychology 8, 53-73.

Bradley E., Curry L., \& Devers K. (2007) Qualitative data analysis for health services research: Developing taxonomy, themes and theory. Health Services Research 42(4), $1758-1772$.

Buckwalter K.C., Gerdner L., Kohout F., Hall G.R., Kelly A., Richards B. \& Sime M. (1999) A nursing intervention to decrease depression in family caregivers of persons with dementia. Archives of Psychiatric Nursing 13, 80-88.

Burgener S.C., Bakas T., Murray C., Dunahee J. \& Tossey S. (1998) Effective caregiving approaches for patients with Alzheimer's Disease. Geriatric Nursing 19, 121-126.

Burgio L., Stevens A., Guy D., Roth D.L. \& Haley W.E. (2003) Impact of two psychosocial interventions on white and African American family caregivers of individuals with dementia. The Gerontologist 43(4), 568-579.

Carr S.M., Lhussier M., Forster N., Geddes L., Deane K., Pennington M., Visram S., White M., Michie S., Donaldson C. \& Hildreth A. (2011) An evidence synthesis of qualitative and quantitative research on component intervention techniques, effectiveness, cost- effectiveness, equity and acceptability of different versions of health-related lifestyle advisor role in improving health. Health Technology Assessment (Winch Eng) 15(9).

This article is protected by copyright. All rights reserved. 
Centre for Reviews and Dissemination (2009) Systematic Reviews: CRD's Guidance for Undertaking Reviews in Health Care. University of York, York.

Challis D., Sutcliffe C., Hughes J., von Abendorff R., Brown P. \& Chesterman J. (2009) Supporting People with Dementia at Home. Ashgate, Farnham.

Challis D., Clarkson P., Hughes J., Chester H., Davies S., Sutcliffe C., Xie C., Abendstern M., Jasper R., Jolley D., Roe B., Tucker S. \& Wilberforce M. (2010) Community Support Services for People with Dementia: The Relative Costs and Benefits of Specialist and Generic Domiciliary Care Services. PSSRU, Manchester.

Chang B.L. (1999) Cognitive-behavioural intervention for homebound caregivers of persons with dementia. Nursing Research 48(3), 173-182.

Chester H., Hughes J., Clarkson P., Davies S. \& Challis, D. (2015) Approaches to information sharing and assessment: evidence from a demonstration program. Care Management Journals 16(3), 150-158.

Chien W.T. \& Lee Y.M. (2008) A Disease management program for families of persons in Hong Kong with dementia. Psychiatric Services 59(4), 433-436.

Chien W.T. \& Lee I.Y.M. (2011) Randomized controlled trial of a dementia care programme for families of home-resided older people with dementia. Journal of Advanced Nursing 67(4), 774-787.

Chu P., Edwards J., Levin J. \& Thompson J. (2000) The use of clinical case management for early stage Alzheimer's patients and their families. American Journal of Alzheimer's Disease and Other Dementias 15, 284-292.

Clarkson P., Giebel C.M., Larbey M., Roe B., Challis D., Hughes J., Jolley D., Poland F. \& Russell I. (2016) A protocol for a systematic review of effective home support to people with dementia and their carers: components and impacts. Journal of Advanced Nursing 72, 186-196.

This article is protected by copyright. All rights reserved. 
Clarkson P., Hughes J., Xie C., Larbey M., Roe B., Giebel C.M., Jolley D., Challis D. \& HoSt-D (Home Support in Dementia) Programme Management Group. (2017) Overview of systematic reviews: Effective home support in dementia care, components and impacts - Stage 1, psychosocial interventions for dementia. Journal of Advanced Nursing 2017;00:1-19. https://doi.org/10.1111/jan.13362.

Cohen J. (1988) Statistical Power Analysis for the Behavioral Sciences (2nd edn.). Lawrence Erlbaum Associates, New York.

Colvez A., Joël M.E., Ponton-Sanchez A. \& Royer A.C. (2002) Health status and work burden of Alzheimer patients' informal caregivers: comparisons of five different care programs in the European Union. Health Policy 60(3), 219-233.

Davis R.N., Massman P.J. \& Doody R.S. (2001) Cognitive intervention in Alzheimer disease: a randomized placebo-controlled study. Alzheimer Disease and Associated Disorders $15,1-9$.

Dias A., Dewey M.E., D'Souza J., Dhume R., Motghare D.D., Shaji K.S., Menon R., Prince M. \& Patel V. (2008) The effectiveness of a home care program for supporting caregivers of persons with dementia in developing countries: a randomised controlled trial from Goa, India. PloS one, 3(6), e2333.

Deeks J.J., Dinnes J., D’Amico R., Sowden A.J., Sakarovitch C., Song F., Petticrew M. \& Altman D.J. (2003) Evaluating non-randomised intervention studies. Health Technology Assessment 7(27).

Department of Health (2009) Living Well with Dementia: A National Dementia Strategy. The Stationery Office, London.

Drentea P., Clay O.J., Roth D.L. \& Mittelman M.S. (2006) Predictors of improvement in social support: Five-year effects of a structured intervention for caregivers of spouses with Alzheimer's Disease. Social Science \& Medicine 63(4), 957-967.

This article is protected by copyright. All rights reserved. 
Effective Public Health Practice Project (EPHPP) (2003) Quality Assessment Tool for Quantitative Studies. Public Health Research, Education and Development Program (PHRED), ON, Canada.

Eisdorfer C., Szaja S.J., Loewenstein D.A., Rubert M.P., Argüelles S., Mitrani B.V. \& Szapocznik J. (2003) The effect of a family therapy and technology based intervention on caregiver depression. Gerontologist 43, 521-531.

Eloniemi-Sulkava U., Saarenheimo M., Laakkonen M.L., Pietilä M., Savikko N., Kautiainen H., Tilvis R.S. \& Pitkälä K.H. (2009) Family care as collaboration: effectiveness of a multicomponent support program for elderly couples with dementia. Randomized controlled intervention study. Journal of the American Geriatrics Society 57(12), 2200-2208.

Eloniemi-Sulkava U., Notkola I.L., Hentinen M., Kivelä S.L., Sivenius J. \& Sulkava R. (2001) Effects of supporting community-living demented patients and their caregivers: A randomized trial. Journal of the American Geriatrics Society 49(10), 1282-1287.

Engelhardt J.B., Kisiel T., Nicholson J., Mulichak L., DeMatteis J. \& Tobin, D.R. (2008) Impact of a care coordination and support strategic partnership on clinical outcomes. Home Healthcare Nursing 26(3), 166-172.

Farran C.J., Loukissa D., Perraud S. \& Paun O. (2003) Alzheimer's disease caregiving information and skills. Part I: care recipient issues and concerns. Research in Nursing \& Health 26(5), 366-75.

Farran C.J., Loukissa D., Perraud S. \& Paun O. (2004) Alzheimer's disease caregiving information and skills. Part II: family caregiver issues and concerns. Research in Nursing \& Health 27(1), 40-51.

This article is protected by copyright. All rights reserved. 
Farran C.J., Gilley D.W., McCann J.J., Bienias J.L., Lindeman D.A. \& Evans D.A. (2007) Efficacy of behavioral interventions for dementia caregivers. Western Journal of Nursing Research 29(8), 944-960.

Finkel S., Czaja S.J., Schulz R., Martinovich Z., Harris C. \& Pezzuto D. (2007) E-care: a telecommunications technology intervention for family caregivers of dementia patients. American Journal of Geriatric Psychiatry 15, 443-448.

Gallagher-Thompson D., Gray H.L., Tang P.C., Pu C.Y., Leung L.Y., Wang P.C., Tse C., Hsu S., Kwo E., Tong H.Q., Long J. \& Thompson L.W. (2007) Impact of in-home behavioral management versus telephone support to reduce depressive symptoms and perceived stress in Chinese caregivers: results of a pilot study. American Journal of Geriatric Psychiatry 15(5), 425-434.

Gavrilova S.I., Ferri C.P., Mikhaylova N., Sokolova O., Banerjee S. \& Prince M. (2009) Helping carers to care - the 10/66 dementia research group's randomized control trial of a caregiver intervention in Russia. International Journal of Geriatric Psychiatry 24, 347-354.

Gitlin L.N., Corcoran M., Winter L., Boyce A. \& Hauck, W. (2001) A randomized, controlled trial of a home environmental intervention. Gerontologist 41(1), 4-14.

Gitlin L.N., Winter L., Corcoran M., Dennis M.P., Schinfeld S. \& Hauck W.W. (2003) Effects of the home environmental skill-building program on the caregiver-care recipient dyad: 6-month outcomes from the Philadelphia REACH Initiative. Gerontologist 43(4), 532-546.

Gitlin L.N., Hauck W.W., Dennis M.P. \& Winter L. (2005) Maintenance of effects of the Home Environmental Skill-Building Program for family caregivers and individuals with Alzheimer's Disease and related disorders. Journal of Gerontological Sciences Series A: Biological Sciences and Medical Sciences 60(3), 368-374.

This article is protected by copyright. All rights reserved. 
Gitlin L.N., Winter L., Burke J., Chernett N., Dennis M.P. \& Hauck W.W. (2008) Tailored activities to manage neuropsychiatric behaviors in persons with dementia and reduce caregiver burden: a randomized pilot study. American Journal of Geriatric Psychiatry 16, 229-239.

Gitlin L.N., Winter L., Dennis M.P., Hodgson N. \& Hauck W.W. (2010a) A biobehavioral home-based intervention and the well-being of patients with dementia and their caregivers: the COPE randomized trial. Journal of the American Medical Association 304, 983-991.

Gitlin L.N., Winter L., Dennis M.P., Hodgson N. \& Hauck W.W. (2010b) Targeting and managing behavioral symptoms in individuals with dementia: A randomized trial of a nonpharmacological intervention. Journal of the American Geriatrics Society 58(8), $1465-1474$.

Graff M.J., Vernooij-Dassen M.J., Thijssen M., Dekker J., Hoefnagels W.H. \& Rikkert M.G. (2006) Community based occupational therapy for patients with dementia and their caregivers: randomised controlled trial. British Medical Journal 333, 1196-1201.

Graff M.J., Vernooij-Dassen M.J., Thijssen M., Dekker J., Hoefnagels W.H. \& Olderikkert M.G. (2007) Effects of community occupational therapy on quality of life, mood and health status in dementia patients and their caregivers: a randomized controlled trial. Journals of Gerontology Series A: Biological Sciences and Medical Sciences 62, $1002-1009$.

Grau H., Graessel E. \& Berth H. (2015) The subjective burden of informal caregivers of persons with dementia: extended validation of the German language version of the Burden Scale for Family Caregivers (BSFC). Aging \& Mental Health 19(2), 159-168.

This article is protected by copyright. All rights reserved. 
Guerra M., Ferri C.P., Fonseca M., Banerjee S. \& Prince, M. (2010) Helping carers to care: the 10/66 dementia research group's randomized control trial of a caregiver intervention in Peru. Revista Brasileira de Psiquiatria 33, 47-54.

Hinchliffe A.C., Hyman I.L., Blizard B. \& Livingston G. (1995) Behavioral complications of dementia - can they be treated. International Journal of Geriatric Psychiatry 10(10), 839-847.

Horvath K.J., Trudeau S.A., Rudolph J.L., Trudeau P.A., Duffy M.E. \& Berlowitz D. (2013) Clinical trial of a home safety toolkit for Alzheimer's disease. International Journal of Alzheimer's Disease 1-11, doi: 10.1155/2013/913606.

Huang H.L., Lotus Shyu Y.I., Chen M.C., Chen S.T. \& Lin L.C. (2003) A pilot study on a home-based caregiver training program for improving caregiver self-efficacy and decreasing the behavioral problems of elders with dementia in Taiwan. International Journal of Geriatric Psychiatry 18, 337-345.

Johnson D.K., Niedens M., Wilson J.R., Swartzendruber L., Yeager A. \& Jones K. (2013) Treatment outcomes of a crisis intervention program for dementia with severe psychiatric complications: The Kansas Bridge Project. Gerontologist 53(1), 102-112.

Kelly A.W., Buckwalter K.C., Hall G., Weaver A.L. \& Butcher H.K. (2002) The caregivers' story: Home caregiving for persons with dementia. Home Health Care Management \& Practice 14(2), 99-109.

Kosloski K. \& Montgomery R.J.V. (1993) The effects of respite on caregivers of Alzheimer's patients: one-year evaluation of the Michigan model respite programs. The Journal of Applied Gerontology 12, 4-17.

Kuo L-M., Huang H-L., Huang H-L., Liang J., Chiu Y-C., Chen S-T., Kwok Y-T., Hsu W-C., Shyu Y-I.L. (2013) A home-based training program improves Taiwanese family 
caregivers' quality of life and decreases their risk for depression: a randomized controlled trial. International Journal of Geriatric Psychiatry 28(5), 504-513.

Kwok T., Wong B., Ip I., Chui K., Young D. \& Ho F. (2013) Telephone-delivered psychoeducational intervention for Hong Kong Chinese dementia caregivers: a singleblinded randomized controlled trial. Clinical Interventions in Ageing 8, 1191-1197.

Lawton M.P., Brody E.M. \& Saperstein A.R. (1989) A controlled study of respite service for caregivers of Alzheimer's patients. Gerontologist 29(1), 8-16.

Liberati A., Altman D.G., Tetzlaff J., Mulrow C., Gotzsche P.C., Ioannidis J.P.A., Clarke M., Devereaux P.J., Kleijnen J. \& Moher D. (2009) The PRISMA Statement for reporting systematic reviews and meta-analyses of studies that evaluate health care interventions: explanation and elaboration. PLoS Medicine. 6(7), e1000100.

Livingston G., Johnston K., Katona C., Paton J. \& Lyketsos C.G. (2005) Systematic review of psychological approaches to the management of neuropsychiatric symptoms of dementia. American Journal of Psychiatry 162, 1996-2021.

Livingston G., Barber J., Rapaport P., Knapp M., Griffin M., King D., Livingston D., Mummery C., Walker Z., Hoe J., Sampson E.L. \& Cooper C. (2013) Clinical effectiveness of a manual based coping strategy programme (START, STrAtegies for RelaTives) in promoting the mental health of family carers of people with dementia: pragmatic randomised controlled trial. British Medical Journal 347, f6276.

Low, L.F. \& Fletcher, J. (2015) Models of home care services for persons with dementia: a narrative review. International Psychogeriatrics 27(10), 1593-1600.

Mahoney D.F., Tarlow B.J. \& Jones R.N. (2003) Effects of an automated telephone support system on caregiver burden and anxiety: findings from the REACH for TLC intervention study. Gerontologist 43(4), 556-567.

This article is protected by copyright. All rights reserved. 
Mittelman M.S., Ferris S.H., Steinberg G., Shulman E., Mackell J.A., Ambinder A. \& Cohen J. (1993) An intervention that delays institutionalization of Alzheimer's disease patients: treatment of spouse-caregivers. Gerontologist 33, 730-740.

Mittelman M.S., Roth D.L., Coon D.W. \& Haley W.E. (2004a) Sustained benefit of supportive intervention for depressive symptoms in caregivers of patients with Alzheimer's disease. American Journal of Psychiatry, 161(5), 850-856.

Mittelman M.S., Roth D.L., Haley W.E. \& Zarit S.H. (2004b) Effects of a caregiver intervention on negative caregiver appraisals of behaviour problems in patients with Alzheimer's Disease: Results of a randomized trial. Journal of Gerontological Sciences Series B: Psychological Sciences and Social Science 59(1), 27-34.

Mittelman M.S., Haley W.E., Clay O.J. \& Roth D.L. (2006) Improving caregiver well-being delays nursing home placement of patients with Alzheimer disease. Neurology 67(9), 1592-1599.

Moher D., Liberati A., Tetzlaff J. \& Altman D.G. (2009) Preferred reporting items for systematic reviews and meta-analyses: the PRISMA Statement. PLoS Medicine 6, e1000097. doi:10.1371/journal.pmed.1000097.

Mohide E.A. (1990) A randomized trial of family caregiver support in the home management of dementia. Journal of the American Geriatrics Society 38, 446-454.

Moniz-Cook E., Elston C., Gardiner E., Agar S., Silver M., Win T. \& Wang M. (2008) Can training community mental health nurses to support family carers reduce behavioural problems in dementia? An exploratory pragmatic randomised controlled trial. International Journal of Geriatric Psychiatry 23(2), 185-191.

Newcomer R., Yordi C., DuNah R., Fox P. \& Wilkinson A. (1999) Effects of the Medicare Alzheimer's Disease demonstration on caregiver burden and depression. Health Services Research 34, 669-689.

This article is protected by copyright. All rights reserved. 
O'Connor D., Pollitt P., Brook C., Reiss B. \& Roth, M. (1991) Does early intervention reduce the number of elderly people with dementia admitted to institutions for long term care? British Medical Journal 302, 871-875.

Phung K.T., Waldorff F.B., Buss D.V., Eckermann A., Keiding N., Rishoj S., Siersma V., Sorensen J., Sogaard R., Sorensen L.V., Vogel A. \& Waldemar G. (2013) A three-year follow-up on the efficacy of psychosocial interventions for patients with mild dementia and their caregivers: the multicentre, rater-blinded, randomised Danish Alzheimer Intervention Study (DAISY). British Medical Journal Open 3(11), doi:10.1136/bmjopen-2013-003584.

Prince M., Knapp M., Guerchet M., McCrone P., Prina M., Comas-Herrera A., Wittenberg R., Adelaja B., Hu B., King D., Rehill A. \& Salimkumar D. (2014) Dementia UK: Update. Alzheimer's Society, London.

Public Health Resource Unit (2006) Critical Appraisal Skills Programme. 10 Questions to help you make sense of qualitative research. Public Health Resource Unit, England.

Quayhagen M.P., Quayhagen M., Corbeil R.R., Hendrix R.C, Jackson J.E., Snyder L. \& Bower D (2000) Coping with dementia: evaluation of four nonpharmacologic interventions. International Psychogeriatrics 12(2), 249-265.

Riordan J.M. \& Bennett A.V. (1998) An evaluation of an augmented domiciliary service to older people with dementia and their carers. Aging \& Mental Health 2(2), 137-143.

Rossor M. \& Knapp M. (2015) Can we model a cognitive footprint of interventions and policies to help meet the global challenge of dementia? The Lancet 386 (9997), 10081010.

Rothera I., Jones R., Harwood R., Avery A., Fisher K., James V., Shaw I. \& Waite J. (2008) An evaluation of a specialist multiagency home support service for older people with

This article is protected by copyright. All rights reserved. 
dementia using qualitative methods. International Journal of Geriatric Psychiatry 23, $65-72$.

Samus Q.M., Johnston D., Black B.S., Hess E., Lyman C., Vavilikolanu A., Pollutra J., Leoutsakos J-M., Gitlin L.N., Rabins P.V. \& Lyketsos C.G. (2014) A multidimensional home-based care coordination intervention for elders with memory disorders: the Maximizing Independence at Home (MIND) pilot randomized trial. American Journal Geriatric Psychiatry 22(4), 398-414.

Schneider, J., Hallam, A., Islam, M.K., Murray, J., Foley, B., Atkins, L., Banerjee, S. \& Mann, A. (2003) Formal and informal care for people with dementia: variations in costs over time. Ageing and Society 23, 303-326.

Starkstein S.E., Jorge R., Mizrahi R. \& Robinson R.G. (2006) A diagnostic formulation of anosognosia in Alzheimer's disease. Journal of Neurology, Neurosurgery \& Psychiatry 77(6), 719-725.

Steinberg M., Leoutsakos J.M., Podewils L.J. \& Lyketsos C.G. (2009) Evaluation of a homebased exercise program in the treatment of Alzheimer's disease: the Maximizing Independence in Dementia (MIND) study. International Journal of Geriatric Psychiatry 24, 680-685.

Sussman T. \& Regehr C. (2009) The influence of community-based services on the burden of spouses caring for their partners with dementia. Health \& Social Work 34(1), 29-39.

Sutcliffe C. \& Larner S. (1988) Counselling carers of the elderly at home: a preliminary study. British Journal of Clinical Psychology 27(2), 177-178.

Sutcliffe C.L., Giebel C.M., Jolley D. \& Challis D.J. (2016) Experience of burden in carers of people with dementia on the margins of care. International Journal of Geriatric Psychiatry 31(2), 101-108.

This article is protected by copyright. All rights reserved. 
Teri L., Gibbons L.E., McCurry S.M., Logsdon R.G., Buchner D.M., Barlow W.E., Kukull W.A., LaCroix A.Z., McCormick W. \& Larson E.B. (2003) Exercise plus behavioral management in patients with Alzheimer disease: a randomized controlled trial. Journal of the American Medical Association 290, 2015-2022.

Teri L., McKenzie G. \& LaFazia D. (2005a) Psychosocial treatment of depression in older adults with dementia. Clinical Psychology: Science and Practice 12, 303-316.

Teri L., McCurry S.M., Logsdon R. \& Gibbons L.E. (2005b) Training community consultants to help family members improve dementia care: a randomized controlled trial. Gerontologist 45, 802-811.

Thomas J. \& Harden A. (2008) Methods for the thematic analysis of qualitative research in systematic reviews. BMC Medical Research Methodology 8, 45.

Tibaldi V., Aimonino N., Ponzetto M., Stasi M.F., Amati D., Raspo S., Roglia D., Molaschi M. \& Fabris F. (2004) A randomized controlled trial of a home hospital intervention for frail elderly demented patients: behavioral disturbances and caregiver's stress. Archives of Gerontology \& Geriatrics Suppl 9, 431-436.

Tong, A., Flemming, K., McInnes, E., Oliver, S. \& Craig, J. (2012) Enhancing transparency in reporting the synthesis of qualitative research: ENTREQ. BMC Medical Research Methodology 12, 181.

Torkamani M., McDonald L., Saez Aguayo I., Kanios C., Katsanou M.N., Madeley L., Limousin P.D., Lees A.J., Haritou M., Jahanshahi M. \& ALADDIN Collaborative Group. (2014). A randomized controlled pilot study to evaluate a technology platform for the assisted living of people with dementia and their carers. Journal of Alzheimer's Disease 41, 515-523.

This article is protected by copyright. All rights reserved. 
Vernooij-Dassen M., Lamers C., Bor J., Felling A. \& Grol, R. (2000) Prognostic factors of effectiveness of a support program for caregivers of dementia patients. International Journal of Aging and Human Development 51(4), 259-274.

Vickrey B.G., Mittman B.S., Connor K.I., Pearson M.L., Della Penna R.D., Ganiats T.G., DeMonte R.W., Chodosh J., Cui X., Vassar S., Duan N., \& Lee M. (2006) The effect of a disease management intervention on quality and outcomes of dementia care: a randomized, controlled trial. Annals of Internal Medicine 145, 713-726.

Wilberforce, M., Tucker, S., Abendstern, M., Brand, C., Giebel, C.M. \& Challis, D. (2013) Membership and management: structures of inter-professional working in community mental health teams for older people in England. International Psychogeriatrics 25(9), $1485-1492$.

Winter L. \& Gitlin L.N. (2006) Evaluation of a telephone-based support group intervention for female caregivers of community-dwelling individuals with dementia. American Journal of Alzheimer's Disease and other Dementias 21(6), 391-397.

Woods R.T., Wills W., Higginson I.J., Hobbins J. \& Whitby, M. (2003) Support in the community for people with dementia and their carers: a comparative outcome study of specialist mental health service interventions. International Journal of Geriatric Psychiatry 18, 298-307.

This article is protected by copyright. All rights reserved. 
Table 1 Review of home support interventions to carers

\begin{tabular}{|c|c|c|c|c|c|c|c|c|}
\hline Author & Country & $\begin{array}{l}\text { Intervention } \\
\text { intensity: } \\
\text { Duration } \\
\text { (Frequency) }^{2}\end{array}$ & $\begin{array}{l}\text { Study } \\
\text { design }\end{array}$ & Sample size & $\begin{array}{l}\text { Dementia } \\
\text { stage }^{3}\end{array}$ & Intervention description & Outcomes $^{4}$ & $\begin{array}{l}\text { Quality } \\
\text { rating }\end{array}$ \\
\hline Belle et al. (2006) & US & $\begin{array}{c}6 \mathrm{~m} \\
(12 \text { sessions })\end{array}$ & RCT & $\begin{array}{l}N_{l}=261 \& \\
N_{C}=257\end{array}$ & $\begin{array}{l}\text { Early and } \\
\text { Later }\end{array}$ & $\begin{array}{l}\text { Information, problem solving, telephone } \\
\text { support, stress management techniques vs } \\
\text { educational materials by post }\end{array}$ & $\begin{array}{l}\text { Time to } \mathrm{NH} \\
\text { admission; Carer } \\
\text { burden; Carer } \\
\text { mood }\end{array}$ & 2 \\
\hline $\begin{array}{l}\text { Bourgeois et al. } \\
(1997)\end{array}$ & UK & $\begin{array}{c}3 \mathrm{~m} \\
\text { (13 sessions) }\end{array}$ & Q-Exp & $N_{1}=7 \& N_{C}=7$ & Later & Behaviour management intervention & PwD behavior & 1 \\
\hline $\begin{array}{l}\text { Bourgeois et al. } \\
(2002)\end{array}$ & US & $\begin{array}{c}3 \mathrm{~m} \\
(13 \text { sessions })\end{array}$ & RCT & $\begin{array}{l}N_{11}=22 \\
N_{12}=21 \& \\
N_{C}=20\end{array}$ & Later & $\begin{array}{l}\text { Two skills training approaches (change } \\
\text { patient behaviour; change own (carer) } \\
\text { coping behaviour) }\end{array}$ & $\begin{array}{l}\text { PwD behavior; } \\
\text { Carer mood }\end{array}$ & 1 \\
\hline $\begin{array}{l}\text { Buckwalter et al. } \\
\text { (1999) }\end{array}$ & US & $\begin{array}{c}6 \mathrm{~m} \\
\text { (13 sessions) }\end{array}$ & RCT & $\begin{array}{l}N_{l}=132 \& \\
N_{C}=108\end{array}$ & nk & $\begin{array}{l}\text { Teaching techniques to carers to reduce } \\
\text { behavioural problems of PwD, i.e. } \\
\text { environmental adaptations }\end{array}$ & Carer mood & 2 \\
\hline Burgio et al. (2003) & US & $\begin{array}{c}12 \mathrm{~m} \\
(16 \text { sessions })^{5}\end{array}$ & RCT & $\begin{array}{l}N_{1}=70 \& \\
N_{C}=70\end{array}$ & $\begin{array}{l}\text { Early and } \\
\text { Later }\end{array}$ & $\begin{array}{l}\text { Information on behaviour management, } \\
\text { problem solving skills, cognitive restructuring } \\
\text { vs minimal support condition }\end{array}$ & $\begin{array}{l}\text { Carer mood; Time } \\
\text { to } \mathrm{NH} \text { admission; } \\
\text { PwD behavior }\end{array}$ & 1 \\
\hline Colvez et al. (2002) & Europe & Not specified & Q-Exp & $\begin{array}{l}\mathrm{N}_{11}=36 \\
\mathrm{~N}_{12}=50 \\
\mathrm{~N}_{13}=99 \\
\mathrm{~N}_{14}=100 \& \\
\mathrm{~N}_{15}=37\end{array}$ & $\begin{array}{l}\text { Early and } \\
\text { Later }\end{array}$ & $\begin{array}{l}\text { Home social services; day centres; expert } \\
\text { centres; group-living; respite hospitalisation }\end{array}$ & $\begin{array}{l}\text { Carer burden [for } \\
\text { group living and } \\
\text { home social } \\
\text { services] }\end{array}$ & 1 \\
\hline Drentea et al. (2006) & US & $\begin{array}{c}4 \mathrm{~m} \\
\text { (2 sessions) }\end{array}$ & RCT & $\begin{array}{l}N_{1}=94 \& \\
N_{C}=89\end{array}$ & nk & $\begin{array}{l}\text { Individual and family counselling, support } \\
\text { group, ad hoc counselling }\end{array}$ & Social support & 1 \\
\hline Eisdorfer et al. (2003) & US & $\begin{array}{c}12 \mathrm{~m} \\
(26 \text { sessions) }\end{array}$ & RCT & $\begin{array}{l}\mathrm{N}_{11}=54 \\
\mathrm{~N}_{12}=59 \& \\
\mathrm{~N}_{\mathrm{C}}=41\end{array}$ & $\begin{array}{l}\text { Early and } \\
\text { Later }\end{array}$ & $\begin{array}{l}\text { Structural ecosystems therapy; structural } \\
\text { ecosystems therapy + computer-telephone } \\
\text { integrated system; minimal support control }\end{array}$ & $\begin{array}{l}\text { Carer mood [for } \\
\text { therapy }+ \\
\text { technology } \\
\text { intervention] }\end{array}$ & 1 \\
\hline Farran et al. (2007) & US & $\begin{array}{c}12 \mathrm{~m} \\
\text { (14 sessions) }\end{array}$ & RCT & $\begin{array}{l}N_{l}=143 \& \\
N_{C}=153\end{array}$ & $\begin{array}{l}\text { Early and } \\
\text { Later }\end{array}$ & $\begin{array}{l}\text { Caregiver Skill Building Programme (5 } \\
\text { weekly group session \& } 7 \text { individual weekly } \\
\text { telephone sessions }+2 \text { groups session, one } \\
\text { at } 6 \text { and one at } 12 \text { months + telephone } \\
\text { contact when needed) vs. Information and } \\
\text { Support Oriented Therapies }\end{array}$ & $\begin{array}{l}\text { Carer burden [for } \\
\text { CSB] }\end{array}$ & 2 \\
\hline Finkel et al. (2007) & US & $\begin{array}{c}6 \mathrm{~m} \\
(14 \text { sessions })\end{array}$ & RCT & $\begin{array}{l}\mathrm{N}_{1}=23 \& \\
\mathrm{~N}_{\mathrm{C}}=23\end{array}$ & $\begin{array}{l}\text { Early and } \\
\text { Later }\end{array}$ & $\begin{array}{l}\text { Technology-based psychoeducational } \\
\text { intervention by community-based social } \\
\text { service agency (information, strategies for } \\
\text { safety enhancement, social support, }\end{array}$ & $\begin{array}{l}\text { Carer burden; } \\
\text { Carer mood }\end{array}$ & 1 \\
\hline
\end{tabular}

This article is protected by copyright. All rights reserved. 


\begin{tabular}{|c|c|c|c|c|c|c|c|c|}
\hline & & & & & & $\begin{array}{l}\text { management of behaviors) vs information } \\
\text { only }\end{array}$ & & \\
\hline $\begin{array}{l}\text { Gallagher-Thompson } \\
\text { et al. (2007) }\end{array}$ & US & $\begin{array}{c}4 \mathrm{~m} \\
\text { (7 sessions) }\end{array}$ & RCT & $\begin{array}{l}N_{1}=22 \& \\
N_{C}=23\end{array}$ & nk & $\begin{array}{l}\text { In-home behavioral management program } \\
\text { (six modules: introduction, behaviour } \\
\text { management, unhelpful thoughts, } \\
\text { communication issues, end-of-life, pleasant } \\
\text { events) vs. telephone-based comparison } \\
\text { treatment }\end{array}$ & $\begin{array}{l}\text { Carer burden; PwD } \\
\text { mood }\end{array}$ & 1 \\
\hline $\begin{array}{l}\text { Gavrilova et al. } \\
\text { (2009) }\end{array}$ & Russia & $\begin{array}{c}1 \mathrm{~m} \\
\text { (5 sessions) }\end{array}$ & RCT & $\begin{array}{l}N_{1}=25 \& \\
N_{C}=28\end{array}$ & nk & $\begin{array}{l}\text { Education about dementia and strategies for } \\
\text { managing behaviour +usual medical care vs } \\
\text { Usual medical care only (control) }\end{array}$ & $\begin{array}{l}\text { Carer burden; PwD } \\
\text { mood; PwD } \\
\text { behavior; PwD QoL }\end{array}$ & 1 \\
\hline Gitlin et al. (2003) & US & $\begin{array}{c}6 \mathrm{~m} \\
\text { (10 sessions) }\end{array}$ & RCT & $\begin{array}{l}N_{l}=89 \& \\
N_{C}=109\end{array}$ & $\begin{array}{l}\text { Early and } \\
\text { Later }\end{array}$ & $\begin{array}{l}\text { [Home Environmental Skill-Building } \\
\text { Programme] five home contacts and } 1 \\
\text { telephone contact (by OT, focusing on } \\
\text { education, problem-solving, training and } \\
\text { adaptive equipment) }\end{array}$ & $\begin{array}{l}\text { Carer burden; } \\
\text { Carer QoL }\end{array}$ & 1 \\
\hline Guerra et al. (2010) & Peru & $\begin{array}{c}1 \mathrm{~m} \\
(5 \text { sessions) }\end{array}$ & RCT & $\begin{array}{l}N_{1}=29 \& \\
N_{C}=29\end{array}$ & $\begin{array}{l}\text { Early and } \\
\text { Later }\end{array}$ & $\begin{array}{l}5 \text { weekly home sessions about assessment, } \\
\text { education and behaviour management }\end{array}$ & $\begin{array}{l}\text { Carer burden; } \\
\text { Carer QoL; PwD } \\
\text { QoL; PwD behavior }\end{array}$ & 1 \\
\hline Horvath et al. (2013) & US & $\begin{array}{c}6 \mathrm{~m} \\
\text { (1 session) }\end{array}$ & $\mathrm{RCT}$ & $\begin{array}{l}N_{1}=60 \& \\
N_{C}=48\end{array}$ & $\begin{array}{l}\text { Early and } \\
\text { Later }\end{array}$ & Home Safety toolkit vs customary care & Carer burden & 1 \\
\hline Kelly et al. (2002) & US & Not specified & Qual & Total $\mathrm{N}=226$ & $\begin{array}{l}\text { Early and } \\
\text { Later }\end{array}$ & $\begin{array}{l}\text { Psychoeducational nursing/home care } \\
\text { intervention vs comparison group } \\
\text { (information only) }\end{array}$ & $\begin{array}{l}\text { Carer burden } \\
\text { [themes] }\end{array}$ & $\begin{array}{l}\text { Medium } \\
\text { quality }^{6}\end{array}$ \\
\hline $\begin{array}{l}\text { Kosloski \& } \\
\text { Montgomery (1993) }\end{array}$ & US & $\begin{array}{c}6 \mathrm{~m} \\
\text { (Flexible) } \\
\end{array}$ & Q-Exp & $\begin{array}{l}N_{1}=45 \& \\
N_{C}=25\end{array}$ & nk & Carer respite & $\begin{array}{l}\text { Carer burden [on } \\
\text { subjective burden] }\end{array}$ & 1 \\
\hline Kuo et al. (2013) & Taiwan & $\begin{array}{c}6 \mathrm{~m} \\
\text { (9 sessions) }\end{array}$ & RCT & $\begin{array}{l}N_{1}=63 \& \\
N_{C}=66\end{array}$ & nk & $\begin{array}{l}\text { Home-based training programme (based on } \\
\text { Progressively Lowered Stress Threshold } \\
\text { model, make adaptations to the environment } \\
\text { to reduce PwD problematic behaviour and } \\
\text { reduce carer stress) vs attention control }\end{array}$ & $\begin{array}{l}\text { Carer QoL; Carer } \\
\text { mood }\end{array}$ & 3 \\
\hline Kwok et al. (2013) & China & $\begin{array}{c}3 \mathrm{~m} \\
\text { (12 sessions) }\end{array}$ & RCT & $\begin{array}{l}\mathrm{N}_{1}=18 \& \\
\mathrm{~N}_{\mathrm{C}}=20\end{array}$ & nk & $\begin{array}{l}\text { Telephone-based carer intervention } \\
\text { (psychoeducation from social worker) }\end{array}$ & Carer burden & 1 \\
\hline Lawton et al. (1989) & US & $\begin{array}{c}12 \mathrm{~m} \\
\text { (Flexible) }\end{array}$ & RCT & $\begin{array}{l}\mathrm{N}_{\mathrm{l}}=317 \& \\
\mathrm{~N}_{\mathrm{C}}=315\end{array}$ & nk & Carer respite & $\begin{array}{l}\text { Carer QoL; Carer } \\
\text { burden; PwD } \\
\text { mood; Time to NH } \\
\text { admission }\end{array}$ & 1 \\
\hline $\begin{array}{l}\text { Livingston et al. } \\
\text { (2013) }\end{array}$ & UK & $\begin{array}{c}4 \mathrm{~m} \\
\text { (8 sessions) }\end{array}$ & RCT & $\begin{array}{l}\mathrm{N}_{\mathrm{l}}=173 \& \\
\mathrm{~N}_{\mathrm{C}}=87\end{array}$ & nk & $\begin{array}{l}\text { Manual based coping strategies } \\
\text { (psychoeducation about dementia, behaviour } \\
\text { management, changing unhelpful thoughts, } \\
\text { relaxation) vs treatment as usual }\end{array}$ & $\begin{array}{l}\text { Carer mood; Carer } \\
\text { burden; PwD QoL }\end{array}$ & 2 \\
\hline
\end{tabular}

This article is protected by copyright. All rights reserved. 


\begin{tabular}{|c|c|c|c|c|c|c|c|c|}
\hline Mahoney et al. (2003) & US & $\begin{array}{c}12 \mathrm{~m} \\
(52 \text { sessions) }\end{array}$ & RCT & $\begin{array}{l}N_{l}=49 \& \\
N_{C}=51\end{array}$ & $\begin{array}{l}\text { Early and } \\
\text { Later }\end{array}$ & $\begin{array}{l}\text { Integrated telephone network system } \\
\text { support and weekly computer caregiver } \\
\text { conversations (software) }\end{array}$ & $\begin{array}{l}\text { Carer burden; PwD } \\
\text { mood }\end{array}$ & 2 \\
\hline $\begin{array}{l}\text { Mittelman et al. } \\
\text { (1993) }\end{array}$ & US & $\begin{array}{c}4 \mathrm{~m} \\
(6 \text { sessions }+ \\
\text { support groups/ } \\
\text { counselling) }\end{array}$ & RCT & $\begin{array}{l}N_{l}=103 \& \\
N_{C}=103\end{array}$ & nk & $\begin{array}{l}\text { Individual and family counselling, support } \\
\text { groups, ad hoc consultation vs routine } \\
\text { support }\end{array}$ & $\begin{array}{l}\text { Time to } \mathrm{NH} \\
\text { admission }\end{array}$ & 2 \\
\hline $\begin{array}{l}\text { Mittelman et al. } \\
\text { (2004a) }\end{array}$ & US & $\begin{array}{c}4 \mathrm{~m} \\
\text { (6 sessions }+ \\
\text { support groups/ } \\
\text { counselling) } \\
\end{array}$ & RCT & $\begin{array}{l}\mathrm{N}_{\mathrm{l}}=203 \& \\
\mathrm{~N}_{\mathrm{C}}=203\end{array}$ & $\begin{array}{l}\text { Early and } \\
\text { Later }\end{array}$ & Counselling, support groups & Carer mood & 2 \\
\hline $\begin{array}{l}\text { Mittelman et al. } \\
\text { (2004b) }\end{array}$ & US & $\begin{array}{c}4 \mathrm{~m} \\
\text { (6 sessions }+ \\
\text { support groups/ } \\
\text { counselling) } \\
\end{array}$ & RCT & $\begin{array}{l}\mathrm{N}_{\mathrm{l}}=203 \& \\
\mathrm{~N}_{\mathrm{C}}=203\end{array}$ & $\begin{array}{l}\text { Early and } \\
\text { Later }\end{array}$ & Counselling, support groups & Carer burden & 1 \\
\hline Mohide (1990) & Canada & $\begin{array}{c}6 \mathrm{~m} \\
(26 \text { sessions })\end{array}$ & RCT & $\begin{array}{l}N_{l}=30 \& \\
N_{C}=30\end{array}$ & Later & $\begin{array}{l}\text { Carer-focused health care, education, in- } \\
\text { home respite, support group }\end{array}$ & $\begin{array}{l}\text { Carer QoL; NH } \\
\text { admission }\end{array}$ & 1 \\
\hline $\begin{array}{l}\text { Moniz-Cook et al. } \\
\text { (2008) }\end{array}$ & UK & $\begin{array}{l}1 \mathrm{~m} \\
(4 \text { sessions }+ \\
\text { flexible contact) }\end{array}$ & RCT & $\begin{array}{l}\mathrm{N}_{\mathrm{l}}=54 \& \\
\mathrm{~N}_{\mathrm{C}}=59\end{array}$ & nk & $\begin{array}{l}\text { Psychosocial intervention on managing } \\
\text { behaviour from trained (experimental) CMHN } \\
\text { or usual care (control) CMHN }\end{array}$ & $\begin{array}{l}\text { PwD behavior; } \\
\text { Carer mood }\end{array}$ & 2 \\
\hline $\begin{array}{l}\text { Sussman \& Regehr } \\
\text { (2009) }\end{array}$ & Canada & Not specified & Q-Exp & $\mathrm{N}_{1}=85$ & $\begin{array}{l}\text { Early and } \\
\text { Later }\end{array}$ & $\begin{array}{l}\text { Homemaking service vs adult day program } \\
\text { services (respite) vs in-home professional } \\
\text { support services }\end{array}$ & $\begin{array}{l}\text { Carer burden [for } \\
\text { day centres] }\end{array}$ & 2 \\
\hline $\begin{array}{l}\text { Sutcliffe \& Larner } \\
\text { (1988) }\end{array}$ & UK & $\begin{array}{c}4.5 \mathrm{~m} \\
\text { (6 sessions) }\end{array}$ & RCT & $\begin{array}{l}N_{11}=6, N_{12}=4 \\
\& N_{C}=5\end{array}$ & nk & Emotional support; Information only & $\begin{array}{l}\text { Carer burden[for } \\
\text { emotional support]; } \\
\text { Carer mood }\end{array}$ & 2 \\
\hline $\begin{array}{l}\text { Torkomani et al. } \\
\text { (2014) }\end{array}$ & $\begin{array}{l}\text { UK, Spain, } \\
\text { Greece }\end{array}$ & $\begin{array}{c}6 \mathrm{~m} \\
(1 \text { session }+ \\
\text { flexible })\end{array}$ & RCT & $\begin{array}{l}N_{l}=30 \& \\
N_{C}=30\end{array}$ & $\begin{array}{l}\text { Early and } \\
\text { Later }\end{array}$ & $\begin{array}{l}\text { Telemedicine system providing } \\
\text { information/education, social networking, } \\
\text { monitoring health, contact feature }\end{array}$ & $\begin{array}{l}\text { Carer QoL; Carer } \\
\text { burden; PwD } \\
\text { behavior; Carer } \\
\text { mood }\end{array}$ & 2 \\
\hline $\begin{array}{l}\text { Vernooij-Dassen et al. } \\
(2000)\end{array}$ & Netherlands & $\begin{array}{c}10 \mathrm{~m} \\
\text { (not specified) }\end{array}$ & RCT & $\begin{array}{l}\mathrm{N}_{\mathrm{l}}=73 \text { \& } \\
\mathrm{N}_{\mathrm{C}}=63 ; \text { but } \\
\text { only } \mathrm{N}_{\mathrm{l}}=49 \text { in } \\
\text { admission } \\
\text { analysis \& } \\
\mathrm{N}_{\mathrm{l}}=41 \text { in } \\
\text { carer } \\
\text { competency } \\
\text { analysis }\end{array}$ & $\begin{array}{l}\text { Early and } \\
\text { Later }\end{array}$ & $\begin{array}{l}\text { Information about available support, offering } \\
\text { listening, support positive contribution family } \\
\text { makes to care (amongst others) }\end{array}$ & Family carer skills & 2 \\
\hline Winter \& Gitlin (2006) & US & $\begin{array}{c}6 \mathrm{~m} \\
\text { (26 sessions) }\end{array}$ & RCT & $\begin{array}{l}\mathrm{N}_{1}=58 \& \\
\mathrm{~N}_{\mathrm{C}}=45\end{array}$ & $\begin{array}{l}\text { Early and } \\
\text { Later }\end{array}$ & $\begin{array}{l}\text { Telephone support group ( } 5 \text { carers for an } \\
\text { hour weekly) }\end{array}$ & $\begin{array}{l}\text { Carer mood; Carer } \\
\text { burden }\end{array}$ & 1 \\
\hline Woods et al. (2003) & UK & Not specified & Q-Exp & $\mathrm{N}_{\mathrm{l}}=55$ \& & nk & Admiral Nurse Service vs. Conventional & Carer burden & 3 \\
\hline
\end{tabular}

This article is protected by copyright. All rights reserved. 


\section{\begin{tabular}{|l|l|l|l|l|l}
\hline & & & $\mathrm{N}_{\mathrm{C}}=73$ & & services \\
\hline
\end{tabular}}

${ }^{1}$ Duration of intervention is the length of time over which the active intervention was conducted ( $\mathrm{m}=$ months), not the length of the study evaluation period; ${ }^{2}$ Frequency of intervention is the number of sessions/visits over this period; ${ }^{3}$ Dementia stage: early stage $=$ described as mild to moderate, mean MMSE reported of $26-16$, mean GDR of $>3<=5$; later stage $=$ described as moderate to severe, mean MMSE reported of $0-15$, mean GDR of $>5 ;{ }^{4}$ All outcomes highlighted in italics indicate significant improvements post intervention; ${ }^{5}$ Study only reports 6-months outcomes; ${ }^{6}$ Quality

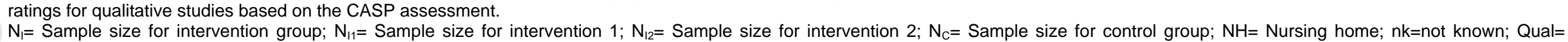
Qualitative; Q-Exp= Quasi-Experimental; RCT = Randomised Controlled Trial 
Table 2 Review of home support interventions to carers and people with dementia

\begin{tabular}{|c|c|c|c|c|c|c|c|c|}
\hline Author & Country & $\begin{array}{l}\text { Intervention } \\
\text { intensity: } \\
\text { Duration }^{1} \\
\text { (Frequency) }^{2}\end{array}$ & $\begin{array}{l}\text { Study } \\
\text { design }\end{array}$ & Sample size & $\begin{array}{l}\text { Dementia } \\
\text { stage }^{3}\end{array}$ & Intervention description & Outcomes $^{4}$ & $\begin{array}{l}\text { Quality } \\
\text { rating }\end{array}$ \\
\hline $\begin{array}{l}\text { Askham \& } \\
\text { Thompson (1990) }\end{array}$ & UK & $\begin{array}{c}12 \mathrm{~m} \\
\text { (flexible) }\end{array}$ & RCT & $\begin{array}{l}\mathrm{N}_{\mathrm{l}}=60 \text { \& } \\
\mathrm{N}_{\mathrm{C}}=40 \text { [at } 6 \\
\text { months]; } \\
\mathrm{N}_{\mathrm{l}}=47 \text { \& } \\
\mathrm{N}_{\mathrm{C}}=44 \text { [at } 12 \\
\text { months] }\end{array}$ & nk & $\begin{array}{l}\text { Different types of services provided } \\
\text { depending on individual: no support; } \\
\text { obtaining/increasing support from other } \\
\text { services; providing continuing direct support; } \\
\text { monitoring situation only; putting in support } \\
\text { workers (help with ADLs, accompanying to } \\
\text { social events, orientation to time and place, } \\
\text { sitting service, companionship) }\end{array}$ & $\begin{array}{l}\text { Time to } \mathrm{NH} \\
\text { admission }\end{array}$ & 2 \\
\hline $\begin{array}{l}\text { Burgener et al. } \\
\text { (1998) }\end{array}$ & US & $\begin{array}{c}1 \mathrm{~m} \\
\text { (1 session) }\end{array}$ & RCT & $\begin{array}{l}N_{11}=11 \\
N_{12}=12 \\
N_{13}=12 \\
\& N_{C}=12\end{array}$ & Later & $\begin{array}{l}\text { Education + behaviour intervention; } \\
\text { education intervention; behaviour } \\
\text { intervention }\end{array}$ & $\begin{array}{l}\text { Person with } \\
\text { dementia behavior } \\
\text { [Intervention } 1 \text { and } \\
\text { 2]; ADLs } \\
\text { [Intervention 3] }\end{array}$ & 1 \\
\hline Challis et al. (2009) & UK & $\begin{array}{c}12 \mathrm{~m} \\
\text { (not specified) }\end{array}$ & Q-Exp & $\begin{array}{l}N_{l}=43 \& \\
N_{C}=43\end{array}$ & Later & Case management & NH admission & 2 \\
\hline Chang (1999) & US & $\begin{array}{c}2 \mathrm{~m} \\
\text { (not specified) }\end{array}$ & RCT & $\begin{array}{l}N_{1}=31 \& \\
N_{C}=34\end{array}$ & $\begin{array}{l}\text { Early and } \\
\text { Later }\end{array}$ & Cognitive-behavioural intervention & Carer mood & 2 \\
\hline Chien \& Lee (2008) & China & $\begin{array}{c}6 \mathrm{~m} \\
\text { (12 sessions) }\end{array}$ & RCT & $\begin{array}{l}\mathrm{N}_{\mathrm{l}}=44 \& \\
\mathrm{~N}_{\mathrm{C}}=44\end{array}$ & $\begin{array}{l}\text { Early and } \\
\text { Later }\end{array}$ & $\begin{array}{l}\text { Education and support group + home visits } \\
\text { by case managers for education and family } \\
\text { health }\end{array}$ & $\begin{array}{l}\text { Time to } \mathrm{NH} \\
\text { admission; Carer } \\
\text { QoL; Carer burden }\end{array}$ & 1 \\
\hline Chien \& Lee (2011) & China & $\begin{array}{c}6 \mathrm{~m} \\
\text { (14 sessions) }\end{array}$ & RCT & $\begin{array}{l}\mathrm{N}_{\mathrm{l}}=46 \& \& \\
\mathrm{~N}_{\mathrm{C}}=46\end{array}$ & nk & $\begin{array}{l}\text { Weekly home visits, education for } \\
\text { assessment, then intervention with individual } \\
\text { families: fortnightly sessions (in total } 102- \\
\text { hour sessions) involving education, problem- } \\
\text { solving, psychological support }\end{array}$ & $\begin{array}{l}\text { Time to } \mathrm{NH} \\
\text { admission; Carer } \\
\text { QoL }\end{array}$ & 1 \\
\hline Chu et al. (2000) & Canada & $\begin{array}{c}18 \mathrm{~m} \\
\text { (Flexible) }\end{array}$ & RCT & $\begin{array}{l}N_{1}=37 \& \\
N_{C}=38\end{array}$ & Early & $\begin{array}{l}\text { Early Home Care Programme (case } \\
\text { management, OT, physical therapy, social } \\
\text { work, respite, etc.) vs. information only }\end{array}$ & $\begin{array}{l}\text { Time to } \mathrm{NH} \\
\text { admission; Carer } \\
\text { burden }\end{array}$ & 1 \\
\hline Dias et al. (2008) & India & $\begin{array}{c}6 \mathrm{~m} \\
\text { (13 sessions) }\end{array}$ & $\mathrm{RCT}$ & $\begin{array}{l}N_{l}=41 \& \\
N_{C}=40\end{array}$ & nk & $\begin{array}{l}\text { Intervention (education about dementia and } \\
\text { behaviour, support for carers, psychiatrist } \\
\text { referrals, networking, advice) vs. waiting list } \\
\text { (receiving intervention after } 6 \text { months) }\end{array}$ & $\begin{array}{l}\text { Carer burden; } \\
\text { Person with } \\
\text { dementia behavior; } \\
\text { ADLs }\end{array}$ & 1 \\
\hline $\begin{array}{l}\text { Eloniemi-Sulkava et } \\
\text { al. (2001) }\end{array}$ & Finland & $\begin{array}{c}24 \mathrm{~m} \\
\text { (Flexible }+20 \\
\text { days training) }\end{array}$ & RCT & $\begin{array}{l}N_{1}=53 \& \\
N_{C}=47\end{array}$ & $\begin{array}{l}\text { Early and } \\
\text { Later }\end{array}$ & $\begin{array}{l}\text { Dementia family care coordinator (advocacy, } \\
\text { training, counselling, in-home visits, etc.) vs } \\
\text { usual care }\end{array}$ & $\mathrm{NH}$ admission & 1 \\
\hline Eloniemi-Sulkava et & Finland & $24 \mathrm{~m}$ & RCT & $\mathrm{N}_{1}=63 \&$ & Early and & Home visits (initial support plan), geriatric & Time to $\mathrm{NH}$ & 2 \\
\hline
\end{tabular}

This article is protected by copyright. All rights reserved. 


\begin{tabular}{|c|c|c|c|c|c|c|c|c|}
\hline al. (2009) & & (6 sessions) & & $\mathrm{N}_{\mathrm{C}}=62$ & Later & $\begin{array}{l}\text { assessments, education, individually tailored } \\
\text { and need-based activities by trained public } \\
\text { health registered nurse, support groups for } \\
\text { carers, information sessions }\end{array}$ & admission & \\
\hline $\begin{array}{l}\text { Engelhardt et al. } \\
\text { (2008) }\end{array}$ & US & Not specified & Q-Exp & $\begin{array}{l}N_{l}=36 \& \\
N_{C}=113\end{array}$ & nk & Telephone health counselling & Hospital admission & 2 \\
\hline Farran et al. (2003) & US & $\begin{array}{c}12 \mathrm{~m} \\
(14 \text { sessions) }\end{array}$ & Qual & Total $\mathrm{N}=177$ & $\begin{array}{l}\text { Early and } \\
\text { Later }\end{array}$ & Caregiver Skill Building Programme & $\begin{array}{l}\text { Carer perceptions } \\
\text { of Person with } \\
\text { dementia } \\
\text { behaviors, ADLs \& } \\
\text { cognitive decline }\end{array}$ & $\begin{array}{l}\text { low } \\
\text { quality }\end{array}$ \\
\hline Farran et al. (2004) & US & $\begin{array}{c}12 \mathrm{~m} \\
\text { (14 sessions) }\end{array}$ & Qual & Total $\mathrm{N}=177$ & $\begin{array}{l}\text { Early and } \\
\text { Later }\end{array}$ & Caregiver Skill Building Programme & Carer burden & $\begin{array}{l}\text { low } \\
\text { quality }^{5}\end{array}$ \\
\hline Gitlin et al. (2001) & US & $\begin{array}{c}3 \mathrm{~m} \\
\text { (5 sessions) }\end{array}$ & RCT & $\begin{array}{l}\mathrm{N}_{1}=93 \& \\
\mathrm{~N}_{\mathrm{C}}=78\end{array}$ & $\begin{array}{l}\text { Early and } \\
\text { Later }\end{array}$ & $\begin{array}{l}\text { Home environmental intervention (caregiver } \\
\text { education about environmental impact on } \\
\text { behaviour, breaking down tasks, involving } \\
\text { other family members) }\end{array}$ & $\begin{array}{l}\text { IADLs; ADLs; } \\
\text { Person with } \\
\text { dementia behavior; } \\
\text { Carer burden }\end{array}$ & 1 \\
\hline Gitlin et al. (2005) & US & $\begin{array}{c}6 \mathrm{~m} \\
\text { (10 sessions) }\end{array}$ & RCT & $\begin{array}{l}N_{l}=65 \& \\
N_{C}=65\end{array}$ & $\begin{array}{l}\text { Early and } \\
\text { Later }\end{array}$ & $\begin{array}{l}\text { Carer intervention for modifying home } \\
\text { environment }\end{array}$ & $\begin{array}{l}\text { Carer burden; } \\
\text { ADLs }\end{array}$ & 3 \\
\hline Gitlin et al. (2008) & US & $\begin{array}{c}4 \mathrm{~m} \\
\text { (8 sessions) }\end{array}$ & RCT & $\begin{array}{l}\mathrm{N}_{l}=30 \text { \& } \\
\mathrm{N}_{\mathrm{C}}=30\end{array}$ & Later & $\begin{array}{l}\text { Six home visits and two telephone chats with } \\
\text { OT; training of different activities (not really } \\
\text { IADLs) }\end{array}$ & $\begin{array}{l}\text { Person with } \\
\text { dementia behavior; } \\
\text { Person with } \\
\text { dementia mood; } \\
\text { Person with } \\
\text { dementia QoL; } \\
\text { Carer mood }\end{array}$ & 1 \\
\hline Gitlin et al. (2010a) & US & $\begin{array}{c}4 \mathrm{~m} \\
\text { (8 sessions) }\end{array}$ & RCT & $\begin{array}{l}N_{l}=102 \& \\
N_{C}=107\end{array}$ & Later & $\begin{array}{l}12 \text { home or telephone contacts (reducing } \\
\text { environmental stressors and improving carer } \\
\text { skills; education and carer training) vs } 3 \\
\text { telephone calls and education }\end{array}$ & $\begin{array}{l}\text { IADLs; } A D L s ; \text { Carer } \\
\text { QoL; Person with } \\
\text { dementia QoL }\end{array}$ & 1 \\
\hline Gitlin et al. (2010b) & US & $\begin{array}{c}4 \mathrm{~m} \\
\text { (8 sessions) }\end{array}$ & RCT & $\begin{array}{l}N_{1}=117 \& \\
N_{C}=122\end{array}$ & $\begin{array}{l}\text { Early and } \\
\text { Later }\end{array}$ & Problem behaviour management skills & $\begin{array}{l}\text { Person with } \\
\text { dementia behavior; } \\
\text { Carer burden; } \\
\text { Carer mood }\end{array}$ & 1 \\
\hline Graff et al. (2006) & Netherlands & $\begin{array}{c}1 \mathrm{~m} \\
\text { (10 sessions) }\end{array}$ & RCT & $\begin{array}{l}\mathrm{N}_{l}=68 \& \& \\
\mathrm{~N}_{\mathrm{C}}=67\end{array}$ & Early & $\begin{array}{l}\text { OT (cognitive and behavioural interventions, } \\
\text { i.e. training Person with dementia to use } \\
\text { aids) }\end{array}$ & $\begin{array}{l}\text { IADLs; Carer } \\
\text { burden }\end{array}$ & 1 \\
\hline Graff et al. (2007) & Netherlands & $\begin{array}{c}1 \mathrm{~m} \\
\text { (10 sessions) }\end{array}$ & RCT & $\begin{array}{l}\mathrm{N}_{\mathrm{l}}=68 \& \& \\
\mathrm{~N}_{\mathrm{C}}=67\end{array}$ & Early & $\begin{array}{l}\text { Occupational therapy sessions (10), } \\
\text { including cognitive and behavioural } \\
\text { interventions with problem solving, etc. }\end{array}$ & $\begin{array}{l}\text { Person with } \\
\text { dementia QoL; } \\
\text { Person with } \\
\text { dementia mood; } \\
\text { Carer burden; } \\
\text { Carer mood }\end{array}$ & 1 \\
\hline
\end{tabular}

This article is protected by copyright. All rights reserved. 


\begin{tabular}{|c|c|c|c|c|c|c|c|c|}
\hline $\begin{array}{l}\text { Hinchliffe et al. } \\
\text { (1995) }\end{array}$ & UK & $\begin{array}{c}4 \mathrm{~m} \\
(6-19 \\
\text { sessions }) \\
\end{array}$ & RCT & $\begin{array}{l}\mathrm{N}_{1}=20 \text { \& } \\
\mathrm{N}_{\mathrm{C}}=13\end{array}$ & $\begin{array}{l}\text { Early and } \\
\text { Later }\end{array}$ & $\begin{array}{l}\text { Medication, psychological measures, and } \\
\text { social measures, such as daytime activities } \\
\text { to reduce night-time disturbances }\end{array}$ & $\begin{array}{l}\text { Person with } \\
\text { dementia behavior; } \\
\text { Carer burden }\end{array}$ & 1 \\
\hline Huang et al. (2003) & Taiwan & $\begin{array}{c}0.5 \mathrm{~m} \\
(2 \text { sessions) }\end{array}$ & $\mathrm{RCT}$ & $\begin{array}{l}N_{1}=24 \& \\
N_{C}=24\end{array}$ & $\begin{array}{l}\text { Early and } \\
\text { Later }\end{array}$ & $\begin{array}{l}\text { Based on Progressively Lowered Threshold } \\
\text { Model, reducing problem behaviour, vs } \\
\text { educational information }\end{array}$ & $\begin{array}{l}\text { Person with } \\
\text { dementia behavior }\end{array}$ & 1 \\
\hline $\begin{array}{l}\text { Johnson et al. } \\
\text { (2013) }\end{array}$ & US & Not specified & Q-Exp & $\begin{array}{l}\mathrm{N}_{1}=77 \& \\
\mathrm{~N}_{\mathrm{C}}=52\end{array}$ & nk & Information, education, counselling & $\begin{array}{l}\text { Carer burden; } \\
\text { Person with } \\
\text { dementia behavior; } \\
\text { Person with } \\
\text { dementia mood; } \\
\text { NH admission }\end{array}$ & 2 \\
\hline $\begin{array}{l}\text { Mittelman et al. } \\
\text { (2006) }\end{array}$ & US & $\begin{array}{c}\text { max } 216 \mathrm{~m} \\
\text { (6 sessions + } \\
\text { support } \\
\text { groups/ } \\
\text { counselling) }\end{array}$ & RCT & $\begin{array}{l}N_{1}=203 \& \\
N_{C}=203\end{array}$ & $\begin{array}{l}\text { Early and } \\
\text { Later }\end{array}$ & $\begin{array}{l}\text { Counselling, support groups, ad hoc } \\
\text { telephone counselling }\end{array}$ & $\begin{array}{l}\text { NH admission; } \\
\text { Carer burden }\end{array}$ & 2 \\
\hline $\begin{array}{l}\text { Newcomer et al. } \\
\text { (1999) }\end{array}$ & US & $\begin{array}{c}36 \mathrm{~m} \\
\text { (not specified) }\end{array}$ & RCT & $\begin{array}{l}N_{l}=2731 \& \\
N_{C}=2576\end{array}$ & $\begin{array}{l}\text { Early and } \\
\text { Later }\end{array}$ & $\begin{array}{l}\text { Carer education, training, support groups, } \\
\text { carer and client case management }\end{array}$ & $\begin{array}{l}\text { Carer burden; } \\
\text { Carer mood }\end{array}$ & 1 \\
\hline $\begin{array}{l}\text { O'Connor et al. } \\
\text { (1991) }\end{array}$ & UK & $\begin{array}{c}24 \mathrm{~m} \\
\text { (not specified) }\end{array}$ & RCT & $\begin{array}{l}N_{l}=86 \& \\
N_{C}=73\end{array}$ & $\begin{array}{l}\text { Early and } \\
\text { Later }\end{array}$ & $\begin{array}{l}\text { Advice, family counselling, liaison, support } \\
\text { groups, respite }\end{array}$ & $\begin{array}{l}\text { Time to } \mathrm{NH} \\
\text { admission }\end{array}$ & 2 \\
\hline Phung et al. (2013) & Denmark & $\begin{array}{c}8-12 \mathrm{~m} \\
(17-20 \\
\text { sessions })\end{array}$ & $\mathrm{RCT}$ & $\begin{array}{l}N_{l}=163 \& \\
N_{C}=167\end{array}$ & Early & $\begin{array}{l}\text { Counselling, information, support, telephone } \\
\text { counselling, log books }\end{array}$ & $\begin{array}{l}\text { Cognition; Person } \\
\text { with dementia QoL; } \\
\text { Person with } \\
\text { dementia mood \& } \\
\text { Carer mood [only } \\
\text { at } 1 \text { y, not at } 2 \text { y] }\end{array}$ & 2 \\
\hline $\begin{array}{l}\text { Quayhagen et al. } \\
(2000)\end{array}$ & UK & $\begin{array}{c}2 \mathrm{~m} \\
\text { (10 sessions) }\end{array}$ & RCT & $\begin{array}{l}\mathrm{N}_{11}=21, \\
\mathrm{~N}_{12}=29, \\
\mathrm{~N}_{13}=22, \\
\mathrm{~N}_{14}=16 \& \\
\mathrm{~N}_{C}=15\end{array}$ & Early & $\begin{array}{l}\text { Cognitive stimulation; dyadic counselling; } \\
\text { dual supportive seminars; early-stage day } \\
\text { care }\end{array}$ & $\begin{array}{l}\text { Cognition } \\
\text { [Cognitive } \\
\text { stimulation]; } \\
\text { Person with } \\
\text { dementia behavior } \\
\text { [Early-stage day } \\
\text { care]; Carer mood } \\
\text { [Cognitive } \\
\text { stimulation] }\end{array}$ & 3 \\
\hline $\begin{array}{l}\text { Riordan \& Bennett } \\
\text { (1998) }\end{array}$ & UK & $\begin{array}{c}12 \mathrm{~m} \\
\text { (Daily } \\
\text { sessions) } \\
\end{array}$ & Q-Exp & $\begin{array}{l}N_{1}=19 \& \\
N_{C}=19\end{array}$ & Later & $\begin{array}{l}\text { Practical and emotional help, information, } \\
\text { advice }\end{array}$ & $\begin{array}{l}\text { Time to } \mathrm{NH} \\
\text { admission }\end{array}$ & 2 \\
\hline Rothera et al. (2008) & UK & Not specified & Qual & $\begin{array}{l}\text { not specified, } \\
\text { but for both } \\
\text { intervention }\end{array}$ & $\begin{array}{l}\text { Early and } \\
\text { Later }\end{array}$ & Multiagency home support service & $\begin{array}{l}\text { Better quality care } \\
\text { of service; time to } \\
\mathrm{NH} \text { admission }\end{array}$ & $\begin{array}{l}\text { high } \\
\text { quality }\end{array}$ \\
\hline
\end{tabular}

This article is protected by copyright. All rights reserved. 


\begin{tabular}{|c|c|c|c|c|c|c|c|c|}
\hline & & & & $\begin{array}{l}\text { service \& } \\
\text { standard } \\
\text { service } \mathrm{N}=82\end{array}$ & & & & \\
\hline Samus et al. (2014) & US & $\begin{array}{c}18 \mathrm{~m} \\
\text { (not specified) }\end{array}$ & RCT & $\begin{array}{l}N_{l}=74 \& \\
N_{C}=114\end{array}$ & $\begin{array}{l}\text { Early and } \\
\text { Later }\end{array}$ & $\begin{array}{l}\text { Care coordination; service referral; } \\
\text { education; skill-building; care monitoring }\end{array}$ & $\begin{array}{l}\text { Time to } \mathrm{NH} \\
\text { admission; Person } \\
\text { with dementia } \mathrm{QoL}\end{array}$ & 1 \\
\hline Teri et al. (2003) & US & $\begin{array}{c}\mathrm{m} \\
\text { (12 sessions }+ \\
\text { daily exercise) }\end{array}$ & RCT & $\begin{array}{l}N_{1}=76 \& \& \\
N_{C}=77\end{array}$ & $\begin{array}{l}\text { Early and } \\
\text { Later }\end{array}$ & $\begin{array}{l}\text { Exercise at home programme for Person with } \\
\text { dementia and carer training in managing } \\
\text { behavior }\end{array}$ & $\begin{array}{l}\text { Time to } \mathrm{NH} \\
\text { admission; Person } \\
\text { with dementia } \\
\text { mood }\end{array}$ & 2 \\
\hline Teri et al. (2005b) & US & $\begin{array}{c}6 \mathrm{~m} \\
\text { (8 sessions }+ \\
4 \text { monthly } \\
\text { follow-up calls) }\end{array}$ & RCT & $\begin{array}{l}N_{l}=47 \& \\
N_{C}=48\end{array}$ & Later & $\begin{array}{l}\text { Behaviour and mood management skills } \\
\text { training (in home sessions and afterwards } \\
\text { telephone calls) vs routine medical care }\end{array}$ & $\begin{array}{l}\text { Carer burden; } \\
\text { Carer mood; } \\
\text { Person with } \\
\text { dementia behavior; } \\
\text { Person with } \\
\text { dementia QoL }\end{array}$ & 1 \\
\hline Tibaldi et al. (2004) & Italy & Not specified & RCT & $\begin{array}{l}N_{1}=56 \& \& \\
N_{C}=53\end{array}$ & Later & $\begin{array}{l}\text { Geriatric Home Hospitalization Service vs. } \\
\text { General Medical Ward }\end{array}$ & $\begin{array}{l}\text { Person with } \\
\text { dementia behavior; } \\
\text { Carer burden }\end{array}$ & 3 \\
\hline Vickrey et al. (2006) & US & $\begin{array}{c}12 \mathrm{~m} \\
\text { (5 sessions) }\end{array}$ & RCT & $\begin{array}{l}\mathrm{N}_{\mathrm{l}}=238 \& \\
\mathrm{~N}_{\mathrm{C}}=170\end{array}$ & nk & $\begin{array}{l}\text { Care management, in-home assessment, } \\
\text { interactive seminars in care issues for carers }\end{array}$ & $\begin{array}{l}\text { Person with } \\
\text { dementia } Q o L\end{array}$ & 3 \\
\hline
\end{tabular}

Duration of intervention is the length of time over which the active intervention was conducted ( $m=$ months), not the length of the study evaluation period; ${ }^{2}$ Frequency of intervention is the number of sessions/visits over this period; ${ }^{3}$ Dementia stage: early stage $=$ described as mild to moderate, mean MMSE reported of $26-16$, mean GDR of $>3<=5$; later stage $=$ described as moderate to severe, mean MMSE reported of $0-15$, mean GDR of $>5 ;{ }^{4}$ All outcomes highlighted in italics indicate significant improvements post intervention; ${ }^{5}$ Quality ratings for qualitative studies based on the CASP assessment.

$N_{1}=$ Sample size for intervention group; $N_{11}=$ Sample size for intervention 1; $N_{12}=$ Sample size for intervention 2; $N_{C}=$ Sample size for control group; NH= Nursing home; nk=not known; Qual= Qualitative; Q-Exp= Quasi-Experimental; RCT = Randomised Controlled Trial

This article is protected by copyright. All rights reserved. 
Table 3 Review of home support interventions to people with dementia

\begin{tabular}{|c|c|c|c|c|c|c|c|c|}
\hline Author & Country & $\begin{array}{l}\text { Intervention } \\
\text { intensity: } \\
\text { Duration }^{1} \\
\text { (Frequency) }^{2} \\
\end{array}$ & $\begin{array}{l}\text { Study } \\
\text { design }\end{array}$ & Sample size & $\begin{array}{l}\text { Dementia } \\
\text { stage }^{3}\end{array}$ & Intervention description & Outcomes $^{4}$ & $\begin{array}{l}\text { Quality } \\
\text { rating }\end{array}$ \\
\hline Davis et al. (2001) & US & $\begin{array}{c}1 \mathrm{~m} \\
(5 \text { sessions }+6 \\
\text { home } \\
\text { exercises } \\
\text { weekly) } \\
\end{array}$ & RCT & $\begin{array}{l}N_{l}=19 \& \\
N_{C}=18\end{array}$ & Early & Testing recall, cognitive stimulation & $\begin{array}{l}\text { Person with dementia } \\
\text { QoL; Person with } \\
\text { dementia mood; } \\
\text { Cognition }\end{array}$ & 1 \\
\hline $\begin{array}{l}\text { Steinberg et al. } \\
\text { (2009) }\end{array}$ & US & $\begin{array}{c}1.5-3 \mathrm{~m} \\
(10 \text { sessions })\end{array}$ & RCT & $\begin{array}{l}N_{1}=14 \& \\
N_{C}=13\end{array}$ & Early & $\begin{array}{l}\text { Exercise programme vs home } \\
\text { safety }\end{array}$ & $\begin{array}{l}\text { Cognition; } A D L s ; \\
\text { Person with dementia } \\
\text { QoL; Person with } \\
\text { dementia behavior; } \\
\text { Person with dementia } \\
\text { mood; Carer burden }\end{array}$ & 1 \\
\hline
\end{tabular}

${ }^{1}$ Duration of intervention is the length of time over which the active intervention was conducted $\left(\mathrm{m}=\right.$ months), not the length of the study evaluation period; ${ }^{2}$ Frequency of intervention is the number of sessions/visits over this period; ${ }^{3}$ Dementia stage: early stage $=$ described as mild to moderate, mean MMSE reported of $26-16$, mean GDR of $>3<=5$; later stage $=$ described as moderate to severe, mean MMSE reported of $0-15$, mean GDR of $>5 ;{ }^{4}$ All outcomes highlighted in italics indicate significant improvements post intervention.

$N_{1}=$ Sample size for intervention group; $N_{11}=$ Sample size for intervention 1; $N_{12}=$ Sample size for intervention 2; $N_{C}=$ Sample size for control group; NH= Nursing home; nk=not known; Qual= Qualitative; Q-Exp= Quasi-Experimental; RCT = Randomised Controlled Trial.

Table 4 Synthesis of home support interventions

\begin{tabular}{|c|c|c|c|c|c|}
\hline $\begin{array}{l}\text { Home support } \\
\text { intervention (single } \\
\text { or multiple } \\
\text { components) }\end{array}$ & Exemplar Intervention & $\begin{array}{l}\text { Mechanisms/t } \\
\text { heory of } \\
\text { change }\end{array}$ & Staff group & Outcomes & Effectiveness rating \\
\hline \multicolumn{6}{|l|}{ Primarily to carers } \\
\hline $\begin{array}{l}\mathrm{C} 1 \text { - Behaviour } \\
\text { management }\end{array}$ & $\begin{array}{l}\text { Caregivers taught to identify and modify } \\
\text { behavioural problems of their relatives } \\
\text { through instruction on how to reduce } \\
\text { occurrence of problems and teaching in } \\
\text { skills to modify precipitants of distress } \\
\text { (Teri et al. 2003) }\end{array}$ & $\mathrm{CR}$ & $\begin{array}{l}\text { Nurse therapists; } \\
\text { occupational therapists; } \\
\text { physical therapists; } \\
\text { psychologists; } \\
\text { researcher }\end{array}$ & $\begin{array}{l}\text { Physical health and } \\
\text { functioning; affective } \\
\text { symptoms/mood; } \\
\text { behavioural problems, } \\
\text { frequency of repetitive } \\
\text { verbalization, ADLs } \\
\text { (person with dementia); }\end{array}$ & $2-5$ (8 studies) \\
\hline
\end{tabular}

This article is protected by copyright. All rights reserved. 


\begin{tabular}{|c|c|c|c|c|c|}
\hline & & & & $\begin{array}{l}\text { caregiver's self- } \\
\text { efficacy/perceived stress; } \\
\text { QoL }\end{array}$ & \\
\hline $\begin{array}{l}\text { C2 - Education/ } \\
\text { advice, emotional \& } \\
\text { social support }\end{array}$ & $\begin{array}{l}\text { A support program, four hours a week } \\
\text { over } 10 \text { months, offered opportunities for } \\
\text { carers to express feelings and problems } \\
\text { and provided practical support } \\
\text { concerning feasible solutions to } \\
\text { problems (Vernooij-Dassen et al. 2000) }\end{array}$ & $\begin{array}{l}\text { IMB; SS/SNT; } \\
\text { EOCS }\end{array}$ & $\begin{array}{l}\text { case managers; home } \\
\text { helps; specialist nurse }\end{array}$ & $\begin{array}{l}\text { Carers' sense of } \\
\text { competence/well-being; } \\
\text { caregiver burden; } \\
\text { admissions to care } \\
\text { homes; behavioural } \\
\text { problems, ADLs; } \\
\text { dementia severity (person } \\
\text { with dementia); caregiver } \\
\text { neuroticism; social } \\
\text { support/social network }\end{array}$ & $1-4$ (6 studies) \\
\hline $\begin{array}{l}\text { C3 - Education/ } \\
\text { advice \& behaviour } \\
\text { management }\end{array}$ & $\begin{array}{l}\text { Caregivers offered home contacts and } \\
\text { one telephone contact and provided with } \\
\text { skills to effectively manipulate } \\
\text { the home environment to manage daily } \\
\text { problems associated with dementia care } \\
\text { (Gitlin et al. 2003) }\end{array}$ & $\begin{array}{l}\text { IMB; CR; } \\
\text { CEPF }\end{array}$ & $\begin{array}{l}\text { Multi-purpose health } \\
\text { workers; nurses; } \\
\text { occupational therapists; } \\
\text { psychologists; } \\
\text { researcher; social } \\
\text { workers }\end{array}$ & $\begin{array}{l}\text { Caregiver objective and } \\
\text { subjective burden; } \\
\text { caregiver well-being and } \\
\text { mood; care recipient } \\
\text { problem behaviours and } \\
\text { physical function; } \\
\text { caregiver skills/efficacy }\end{array}$ & $1-4$ (11 studies) \\
\hline $\begin{array}{l}\text { C4 - Education/ } \\
\text { advice, behaviour } \\
\text { management \& } \\
\text { emotional support }\end{array}$ & $\begin{array}{l}\text { Caregivers offered } \\
\text { education about dementia, carers' } \\
\text { stress, and sources of emotional } \\
\text { support; understanding behaviours of } \\
\text { the family member and behavioural } \\
\text { management techniques; changing } \\
\text { unhelpful thoughts; promoting } \\
\text { acceptance; assertive communication; } \\
\text { relaxation etc. } \\
\text { Carers practised techniques at home, } \\
\text { using a manual and relaxation CDs } \\
\text { (Livingston et al. 2013) }\end{array}$ & $\begin{array}{l}\text { IMB; CR; } \\
\text { EOCS }\end{array}$ & $\begin{array}{l}\text { community workers; } \\
\text { home care nurses; } \\
\text { psychiatrist; psychology } \\
\text { graduates; social } \\
\text { workers }\end{array}$ & $\begin{array}{l}\text { Affective symptoms and } \\
\text { behaviour (person with } \\
\text { dementia); time at } \\
\text { community tenure; } \\
\text { depression and anxiety; } \\
\text { quality of life of carer } \\
\text { and care recipient; } \\
\text { potentially abusive } \\
\text { behaviour by carer } \\
\text { towards care recipient; } \\
\text { carer self-efficacy }\end{array}$ & $1-4$ (5 studies) \\
\hline $\begin{array}{l}\text { C5 - Education/ } \\
\text { advice, behaviour } \\
\text { management \& } \\
\text { social support }\end{array}$ & $\begin{array}{l}\text { Education and support group for carers } \\
\text { with home visits (Chien \& Lee, 1998) or } \\
\text { electronic versions providing individual } \\
\text { and support group sessions to carers } \\
\text { involving information, safety strategies }\end{array}$ & $\begin{array}{l}\text { CR; IMB; } \\
\text { SS/SNT }\end{array}$ & $\begin{array}{l}\text { community nurses; } \\
\text { psychiatrist; respite } \\
\text { workers; social workers }\end{array}$ & $\begin{array}{l}\text { Carer burden; carer } \\
\text { mood; behaviour; NH } \\
\text { admission; carer QoL }\end{array}$ & $3-5$ (5 studies) \\
\hline
\end{tabular}

This article is protected by copyright. All rights reserved. 


\begin{tabular}{|c|c|c|c|c|c|}
\hline & and social support (Finkel et al. 2007) & & & & \\
\hline $\begin{array}{l}\text { C6 -Education/ } \\
\text { advice, behaviour } \\
\text { management, } \\
\text { emotional support \& } \\
\text { social support }\end{array}$ & $\begin{array}{l}\text { Telephone support groups (Winter \& } \\
\text { Gitlin, 2007) or face-to-face support } \\
\text { groups with ad hoc telephone } \\
\text { counselling (Mittelmann et al. 2006) }\end{array}$ & $\begin{array}{l}\text { CR; EOCS; } \\
\text { IMB; SS/SNT }\end{array}$ & Counsellors & $\begin{array}{l}\text { Carer mood; carer } \\
\text { burden; Person with } \\
\text { dementia mood; NH } \\
\text { admission }\end{array}$ & $1-3$ (6 studies) \\
\hline $\begin{array}{l}\text { C7 - Education/ } \\
\text { advice, behaviour } \\
\text { management, } \\
\text { emotional support, } \\
\text { social support \& } \\
\text { respite }\end{array}$ & $\begin{array}{l}\text { Providing information to reduce problem } \\
\text { behaviours (such as increasing activity) } \\
\text { and improving carer coping skills, whilst } \\
\text { also providing options for respite } \\
\text { (Hinchliffe et al. 1995) }\end{array}$ & $\begin{array}{l}\text { CR; EOCS; } \\
\text { HN; IMB; } \\
\text { SS/SNT }\end{array}$ & $\begin{array}{l}\text { Automated conversation } \\
\text { system; counsellor; } \\
\text { psychiatrist }\end{array}$ & $\begin{array}{l}\text { Carer burden; behaviour; } \\
\text { Person with dementia } \\
\text { mood; ADLs }\end{array}$ & $2-4$ (3 studies) \\
\hline \multicolumn{6}{|c|}{ Primarily to persons with dementia } \\
\hline $\begin{array}{l}\text { P1 - Environmental } \\
\text { modifications }\end{array}$ & $\begin{array}{l}\text { Carers and people with dementia } \\
\text { received a home safety toolkit, } \\
\text { containing simple home safety tips. } \\
\text { Carers also received supportive phone } \\
\text { calls (Horvarth et al. 2013). }\end{array}$ & CEPF & Occupational therapists & $\begin{array}{l}\text { Carer burden, carer } \\
\text { mood, carer QoL, } \\
\text { IADLs/ADLs }\end{array}$ & $2-3$ (6 studies) \\
\hline $\begin{array}{l}\text { P2-Care } \\
\text { coordination }\end{array}$ & $\begin{array}{l}\text { Providing a specialist geriatric team at } \\
\text { home and directing to services, with } \\
\text { flexible use targeted at the individual } \\
\text { (Dias et al. 2008; Tibaldi et al. 2004) }\end{array}$ & $\mathrm{CIC}$ & $\begin{array}{l}\text { Counsellors; } \\
\text { geriatricians; nurses; } \\
\text { occupational therapists; } \\
\text { psychiatrists; } \\
\text { physiotherapists; social } \\
\text { workers; }\end{array}$ & $\begin{array}{l}\text { Carer burden; behavior; } \\
\text { NH admission; Carer } \\
\text { QoL; Carer burden }\end{array}$ & $1-5$ (7 studies) \\
\hline
\end{tabular}

Rated taking into account: statistically significant change, effect size and intervention intensity; effectiveness rating range $=1-5$, see supplementary information, File S2.

$\mathrm{CEPF}=$ Competence-Environmental Press Framework $\mathrm{CIC}=$ Continuity and Integration of Care; $\mathrm{CR}=$ Cognitive Restructuring; EOCR = Emotion Oriented Coping Strategies; HN = Hierarchy of Needs; IMB = Information-Motivation-Behavioural Skills model; SS/SNT = Social Support/Social Network Theory

This article is protected by copyright. All rights reserved. 


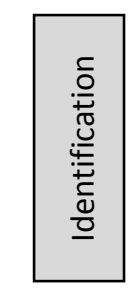

Records identified through database searching ( $n=603)$ :

Known ( $n=113)$; PubMed ( $n=296)$; Cochrane Centre $(n=13)$;

PsychInfo ( $n=46)$;

CINAHL ( $n=27)$; ASSIA ( $n=59)$; Soc Serv Abstracts ( $n=49)$

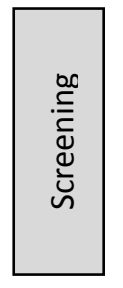

$\downarrow$

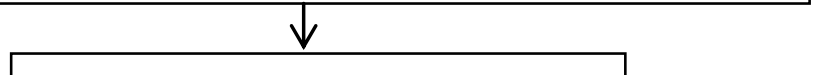
( $n=587)$

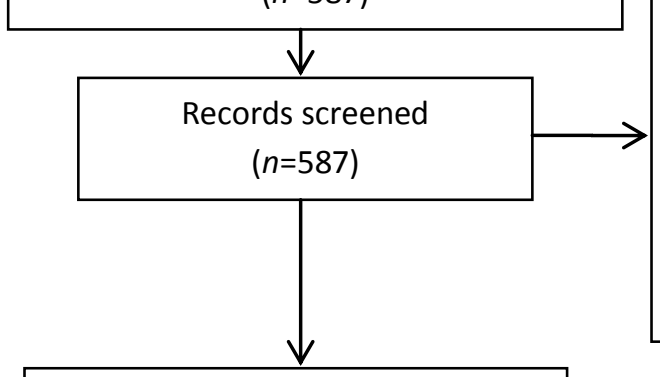

Not dementia ( $n=10)$; Editorial/descriptive study ( $n=295)$; Invasive or drug intervention $(n=3)$; Not at home $(n=16)$; No standard care comparator $(n=3)$; Only cost $(n=1)$; Literature review $(n=55)$; Non English

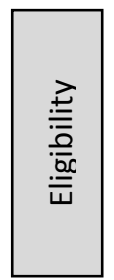
$(n=39) ;$ No designated outcomes $(n=4)$; Protocol only $(n=1)$

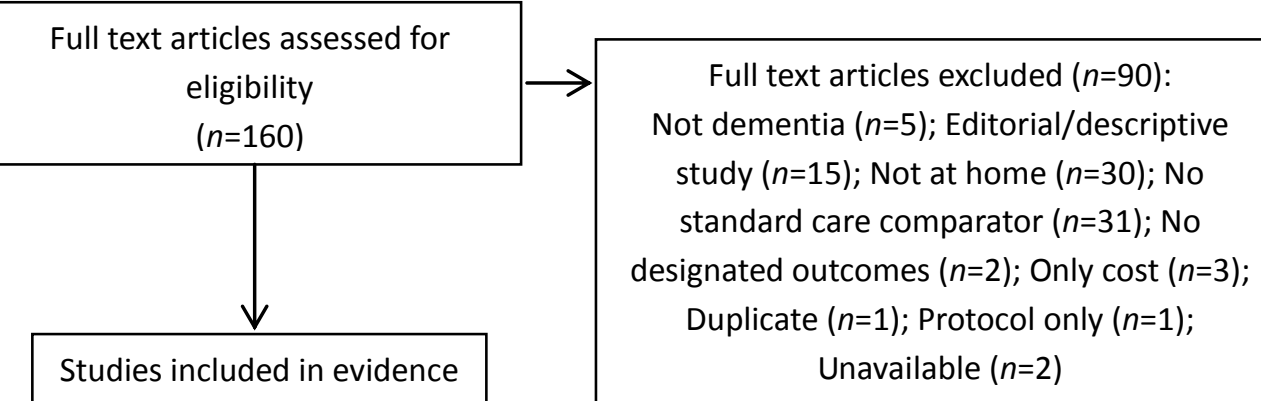

Figure 1 PRISMA flow diagram for included studies

This article is protected by copyright. All rights reserved. 